\title{
CONSTRUCTION STORY OF HASANOĞLAN VILLAGE INSTITUTE, ANKARA
}

\section{ANKARA HASANOĞLAN KÖY ENSTITÜSÜ'NÜN YAPIM HIKKAYESI}

\author{
Makale Bilgisi Article Info \\ Başvuru: 18 Nisan 2021 Received: April 18, 2021 \\ Hakem Değerlendirmesi: 20 Nisan 2021 Peer Review: April 20, 2021 \\ Kabul: 30 Temmuz 2021 Accepted: July 30, 2021
}

DOI : $10.22520 /$ tubaked2021.23.011

\section{Esra EKEN* - Neriman ŞAHIN GÜÇHAN**}

\begin{abstract}
Village Institutes were educational complexes that were designed for 21 villages between 1940 and 1948, as the pioneer of modernization in village development during the Early Republican Period of Turkey. These projects were implemented through architectural competitions and constructed as a campus comprising many buildings instead of a single mass, presenting necessity of the educational understanding in which the integration of theoretical and practical education was the main intention.
\end{abstract}

Hasanoğlan Village Institute (HVI), established in 1941 in Ankara, differs from others, as it was established as a center for training the trainers who may work in village institutes rather than in village schools. Thus, it has a wider architectural program than the other institutes. Additionally, from the first building to the last, the complex was constructed by the students and trainers of 14 institutes that had been previously established. Thus, many people have memories about both the construction process of HVI, in addition to educational life. Despite recent architectural studies about HVI, this specific feature of HVI, focusing on its construction process, has not been narrated in detail.

To fill the gap in the literature, this study aimed to depict the story of HVI through the memories of former students and trainers about the planning and construction phases of its workshops, schools, dining hall, and music complex, and also on-site observations in 2020. Hence, this narrative inquiry began with the background of village institute projects and the significance of Hasanoğlan within the context of village institutes while illustrating the planning phases of the HVI. The construction activities within the institute grounds were then analyzed through memories,

\footnotetext{
Res. Assist., Middle East Technical University, Faculty of Architecture, Department of Architecture, Ankara, Turkey. e-posta: esra.eken.06@gmail.com ORCID: 0000-0001-5036-8979

** Prof. Dr., Middle East Technical University, Department of Architecture, Ankara, Turkey.

e-posta: neriman@metu.edu.tr ORCID: 0000-0001-7841-9344
} 
creating memory map, and on-site observations, considering the local building techniques. In the conclusion, the construction technology, and principles of the modern construction process of the period for institute complexes was evaluated through the example of the HVI.

Keywords: Hasanoğlan, Village Institutes, construction story, Early Republican Architecture.

\section{ÖZET}

Köy Enstitüleri, Türkiye'nin Erken Cumhuriyet Dönemi'nde köy kalkınmasında modernleşmenin öncüsü olarak 1940-1948 yılları arasında 21 köy için tasarlanmış eğitim kompleksleridir. Mimari yarışmalarla hayata geçirilen bu projeler, teorik ve pratik eğitimin birlikteliğinin temel amaç olduğu eğitim anlayışının gerekliliğini ortaya koyan tek bir kütle yerine birçok binadan oluşan kampüsler olarak inşa edilmişlerdir.

1941 y1lında Ankara'da kurulan Hasanoğlan Köy Enstitüsü (HKE), köy okullarından ziyade köy enstitülerinde çalışabilecek eğitmenlerin yetiştirilmesi için bir merkez olarak kurulmuştur. Bu nedenle diğer enstitülere göre daha geniş bir mimari programa sahiptir. Ayrıca bu enstitü, ilk binasından son binasına kadar, daha önce kurulmuş olan 14 enstitünün öğrencileri ve eğitmenleri tarafından inşa edilmiştir. Böylelikle birçok insanın kendi enstitüsündeki eğitim hayatına ek olarak HKE'nün yapım sürecine dair anıları vardır. HKE ile ilgili son zamanlarda yapılmış olan mimari çalışmalarda, HKE'nün yapım hikayesi ayrıntılı olarak ele alınmamıştır.

Literatürdeki boşluğu doldurmak amacıyla, bu çalışma HKE'nün hikayesini, eski öğrenci ve eğitmenlerin anıları üzerinden, atölye, okul, yemekhane ve müzik kompleksi binalarının planlama ve inşaat aşamalarına odaklanarak yerinde gözlemlerle tasvir etmeyi amaçlamaktadır. Çalışmanın ilk bölümü, köy enstitü projelerinin arka planı ve HKE’nün planlama aşamalarını gösterirken, köy enstitüleri bağlamında Hasanoğlan'ın önemi ile başlamaktadır. Sonrasında, enstitü arazisindeki inşaat faaliyetleri yerel inşaat teknikleri dikkate alınarak anılar, bellek haritaları ve yerinde gözlemler aracılığıla analiz edilmiştir. Sonuç olarak, enstitü komplekslerindeki inşaat teknolojisi ve dönemin modern inşaat sürecinin ilkeleri, HKE örneği üzerinden değerlendirilmiş̧ir.

Anahtar Kelimeler: Hasanoğlan, Köy Enstitüleri, yapım hikayesi, Erken Cumhuriyet Dönemi Mimarlı̆̆ı. 


\section{INTRODUCTION}

The 1920s was a significant time in the history of the Turkish Republic in terms of transitioning to a new regime and the occurrence of an economic depression as the result of a long period of war. The industrialization process had slowed down, agricultural production had decreased, and the economy had become dependent on foreign countries. Additionally, the education level was very low and production style was very far from modern techniques. Thus, a rapid educational movement was necessary.

Depending on these shortcomings in the first years of Turkish Republic, economy and education were the main discussed issues. Izmir Economy Congress, which was held between 17 February and 4 March 1923, is so significant as it is the first national platform where economy and education are discussed together (Başgöz $1995,126)$. In the congress the issue of "education in agriculture" was emphasized and seven main decisions were taken regarding this issue. These decisions were mainly based on educating farmers with modern agricultural techniques and establishing schools within large lands that will be suitable for practical agricultural education and accommodation of students and instructors (Başgöz, 1995, 127).

In addition to national congresses, the issue of education remained in the agenda of the 1920s through the examinations and reports of foreign expert educators. John Dewey, education expert who came to Turkey from Germany in 1924, stated that village schools should be established according to the context and schools should be the center for village life (Başgöz 1995, 137). In 1925, another German expert, Dr. Kühne, advised that teacher schools should include garden and field to experience agricultural techniques by students, new alphabet should be adopted to follow innovations, new schools for training technical personnel like architect and engineer should be established and publications in Germany should be followed (Başgöz, 1995, 138). Despite of different suggestions regarding the tools for national education system, the consensus of experts was that agricultural education should be given importance as the Turkish economy was based on agriculture.

With adoption of Latin Alphabet in 1928, literacy movement started in Turkey and Nation Schools (Millet Mektepleri), have been established with the use of government offices. In 1932, these schools were closed, and Public Houses (Halkevleri) in the cities and Public Rooms (Halkodalart) in villages were established more systematically. Main purpose of these institutions was composing national culture, increasing connection between citizens and state, and creating a conscious society (Başgöz 1995, 122). Main activities of these institutions were based on various areas like languagehistory-literature, art, representation, social assistance, public lessons and courses, sports, library science and publication, peasantry, museology, and exhibition, organizing village trips, bringing village education and village development to the agenda. Until their closure on August 11, 1951, with the act numbered 5830, 478 Halkevi, 4322 Halkodası and 330 libraries were established in the whole country (Başgöz 1995, 123).

In addition to establishment of Halkevleri, Village Affairs Commission (Köy İşleri Komisyonu) was established at the Ministry of National Education in 1932 and the qualifications that village teachers should have were determined as those who adopt the principles of revolution, who can affect the social life of the village, who can affect the economic life of the village and who are enlightened (Tonguç, 1998, 446).

The search for a solution to the economy and education problem in Turkey became more concrete with the appointment of İsmail Hakkı Tonguç to the Ministry of National Education as the General Directorate of Primary School in 1935. Tonguç combined statistical data of Turkey and all suggestions of foreign experts for economy and education in their publications. According to official records in Turkey, in $1935,80 \%$ of the total population was made up of people who lived in villages and earned their living from agriculture and animal husbandry. Additionally, nearly $14 \%$ of the villagers were illiterate and $87 \%$ of the villages did not have primary school (Tonguç 1997, 45; Tekben 1962, 8).

According to Tonguç (1998, 94), depending on the country's economy being based on agriculture, the development of the country could be achieved with the development of the village. The first step of village development is to revitalize the village through education. However, this revitalization would start in the villages through living in villages. Tonguç emphasized that the existing graduates from teacher schools in cities were not willing to work and stay in villages. Even if they accepted to work in villages, connection between villagers and teachers could not be created strongly depending on having different lifestyles (Tonguç 1997, 52). Village teachers had to know the values, lifestyle, and problems of the villagers in order to become a leader of them and to solve their problems.

For this purpose, trainer courses (Eğitmen Kurslarl) that were based on training for six months including theoretical and practical education, started to be established in villages in 1936 with the Act numbered 


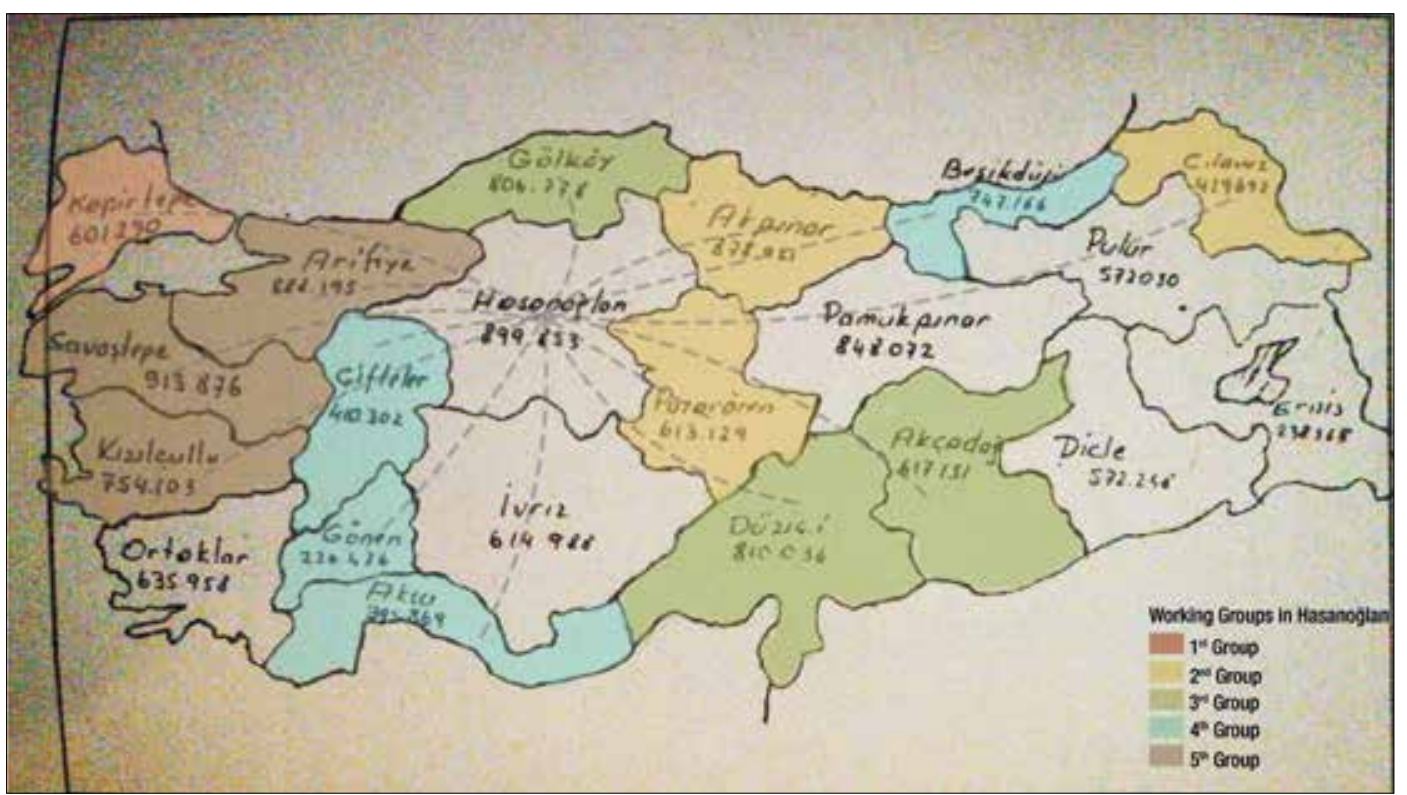

Figure 1. Village institute distribution with the sphere of influence and rural population (colored by the author after Tonguç 1967, 393) / Etki alanları ve kırsal nüfus ile Köy Enstitüleri'nin dağılımı (Tonguç'un 1967, 393 çalışması dikkate alınarak yazar tarafindan renklendirilmiştir.)

3238. According to this law, illiterate people who had completed their military service would be selected and sent to their villages as instructors after their graduation. Main duty of village trainers was pursuing training works and leading agricultural works in the villages. Following, village teacher schools (Köy Ögretmen Okullart) were established in addition to trainer courses. These schools were based on 3 years of education and all people who graduated from primary schools in villages could be enrolled. These school were later converted into village institutes with the Act numbered 3803 in 1940.

The main aim of village institutes established between 1940 and 1944 in 21 sub-regions of Turkey was training village instructors to work in their own villages (Figure 1). In addition to the legal and administrative process of the project (Act numbered 3803), distribution of the institutes was carefully planned, creating spheres of influence (Tonguç 1997, 393). Each institute was located in the center of a determined sphere and trainer candidates from the villages of an average of three cities within the sphere of influence could apply to this institute. Hence, all villages in the country would have equal educational opportunities that combine theoretical and practical knowledge within a complex.

Besides the teaching work of instructors who graduated from village institutes, instructors are intended to be a leader in the daily life of the villagers. According to Village Institutes Law (Act numbered 3803, article 11 and 12), Ministry of National Education would provide the necessary tools, seeds, saplings, and animals for agricultural activities free of charge to the instructors who graduated from the village institutes. Additionally, the
Ministry would allocate adequate land to the instructor in the village where he/she was appointed to provide income source for himself/herself. In this way, the instructor would be a leader of the villagers by applying modern agricultural techniques in his/her exemplary land. Some scholars also state that village institute project was a tool to introduce the components of the new regime and help people to adapt to the new conditions of modern life (Çakıcı and Çorakbaş 2013; Kirby 1962, 65).

Among the village institutes, HVI, which was established in 1941 in Ankara, differs from the others, as it was established as a training center for trainers who may work in village institutes rather than village schools (Figures 1 and 2). Thus, it has a broader architectural program than the other institutes. Additionally, the complex was constructed by the students and trainers of 14 institutes that had been previously established, from the first building to the last (Figure 1). Thus, many people have memories about the construction process of Hasanoğlan, in addition to educational life.

According to aerial photos of the site from 1948, 70 large and small buildings were constructed, including workshops built for practical education, schools built for theoretical education, storages, toilets, dormitories, teacher residences, guest residences, an electric plant, dining hall, activity center, bakery, bath complex, music complex, open-air theater, administrative building, higher institute building, medical building, printing house, garages, stables, coops, and a country house. Additionally, gathering open spaces were organized as ceremonial square and playgrounds in the center of the site (Figure 2a). 


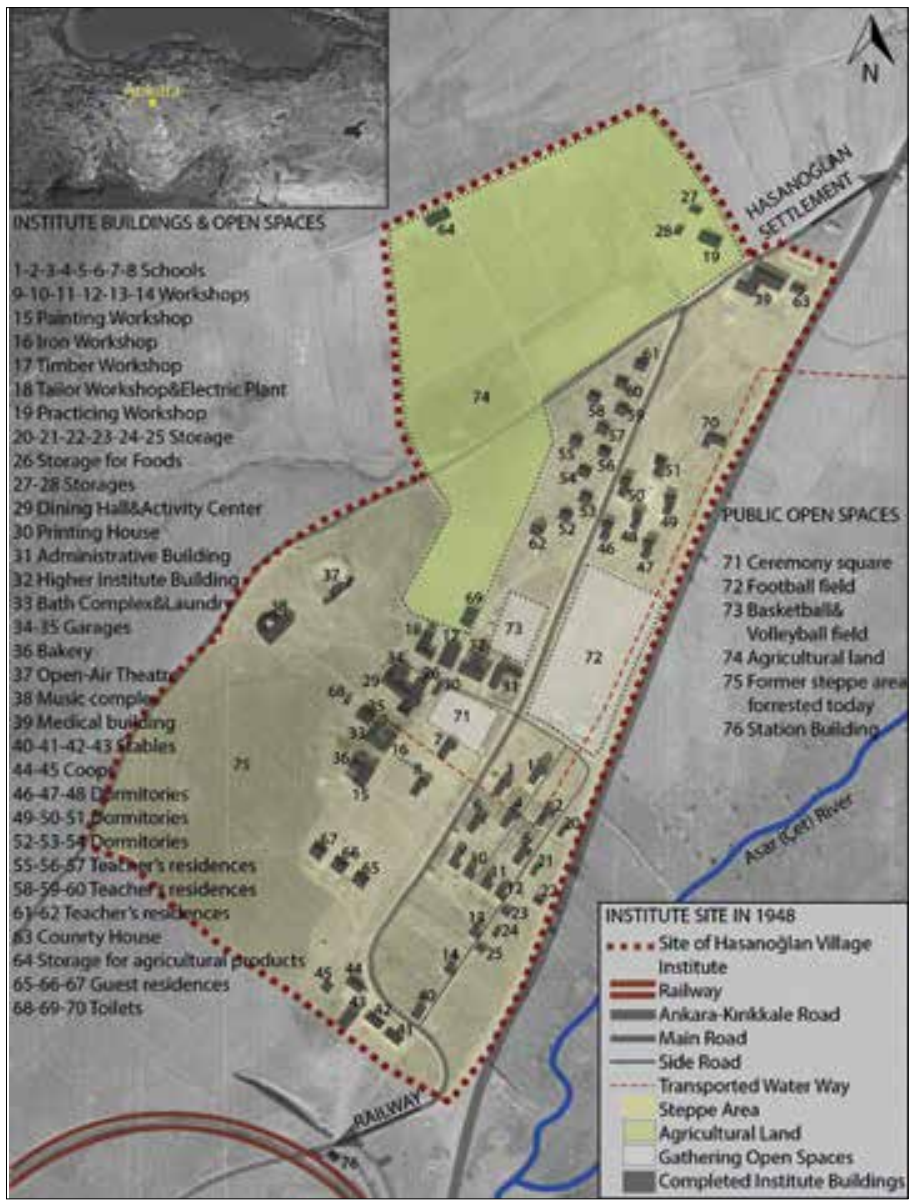

Figure 2a. Building functions and land use in Hasanoğlan Village Institute in 1948 / 1948 yll itibariyle Hasanoğlan Köy Enstitüsü'nde bina fonksiyonları ve alan kullanımı

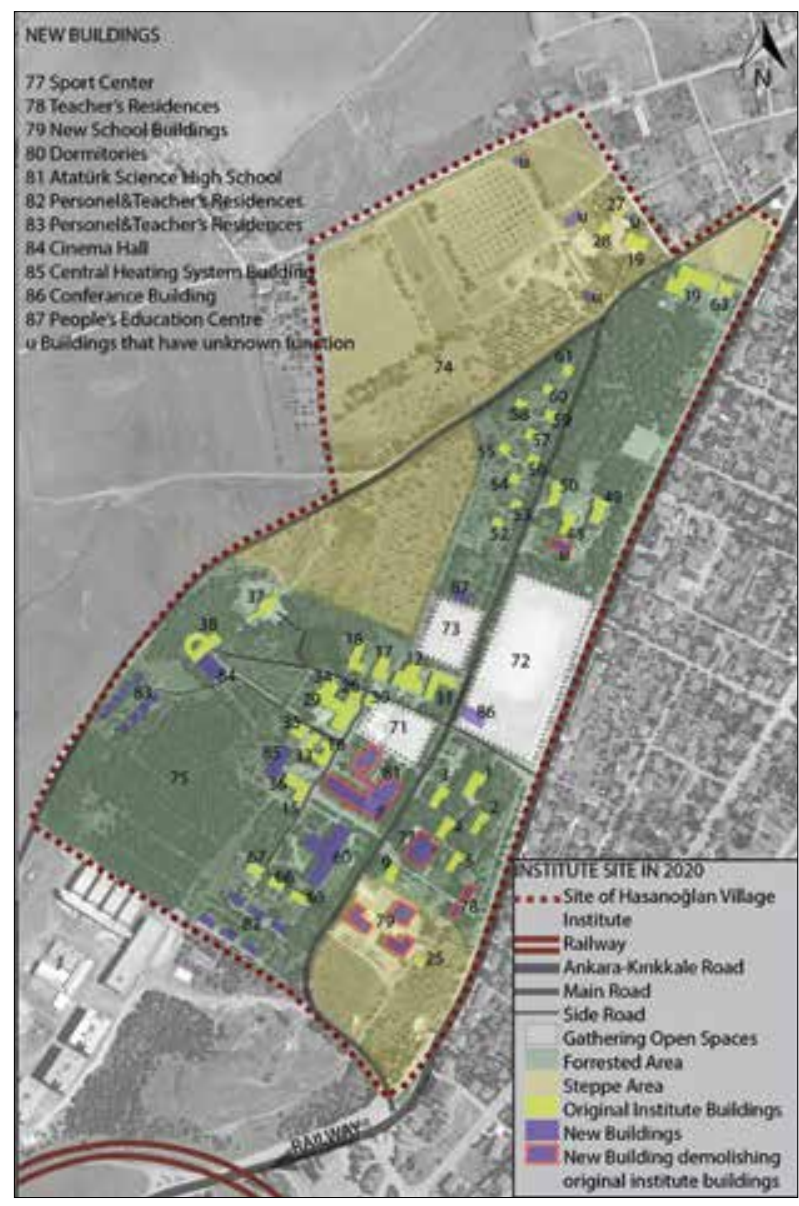

Figure 2b. Building functions and land use in Hasanoğlan Village Institute in 2020 / 2020 yll itibariyle Hasanoğlan Köy Enstitüsü'nde bina fonksiyonları ve alan kullanımı
Originally, two perpendicular axes used to create the functional zones in the institute site. The main one extended in north-south direction, parallel to the AnkaraKırıkkale main road in the east. The other one was perpendicular to the main one and extended towards the music complex and open-air theater (Figure 2a). In addition to the agricultural land in the north, open spaces between the buildings purported as a steppe, as the trees had just been planted.

Recent architectural and conservational studies related to the HVI have mostly been limited to building programs and changes within the complex thus far (Çakı1 1 and Çorakbaş 2019; Mercanoğlu 2019; Çalışkan 2020). However, the story of its construction, including the preparation phase, construction techniques, and materials have been excluded. This study aimed to understand construction story of the HVI through seven books that include memories 19 graduates and former trainers who have been in HVI, in addition to on-site observations. Although the published books that compiled memories of the former students and instructors focusing especially on HVI are quite rich in terms of containing information on many various subjects, these memories were carefully scanned by grouping the main topics discussed and results of this literature survey was tabulated in Table 1. The author has filtered the knowledge on certain subjects including village life and institute enrollment, accommodation process, construction materials, construction technique and building program in these books (Table 1).

Daily fieldwork was conducted by the author in November of 2020 and January of 2021 to observe current situation of the institute site. Ali Kınac1, a graduate from Atatürk Ilkögretmen Okulu (the school that was established in place of HVI after 1954), accompanied the first fieldwork and original institute buildings, buildings that was constructed after 1954, transformations in institute buildings and open spaces until today could be deciphered through his narratives in addition to aerial photos from 1948, 1956, 1975, 1980, 1991, 1999 and 2020. Original and current physical characteristics of the institute site were compared through mapping study.

Based on the outcomes of the memories, this study focused on the HVI, starting at the planning phase, covering the decision for establishment, site selection, 


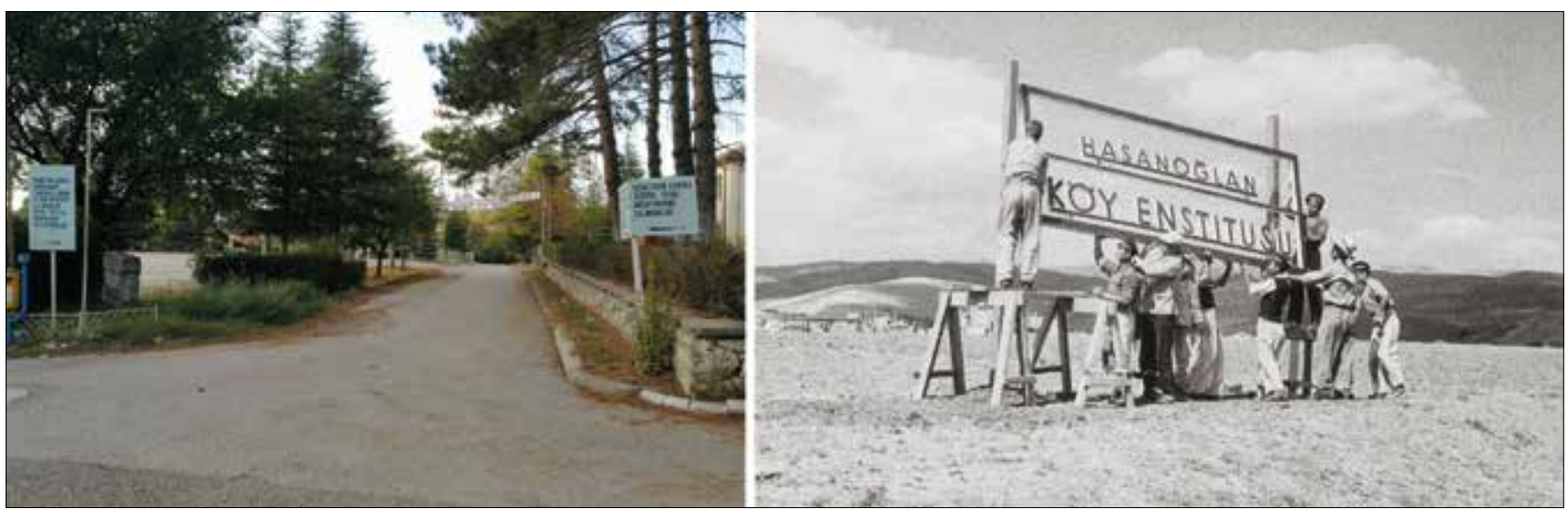

Figure 3: General view of the HVI site at present (left; Eken 2020) and its steppe situation in 1941 (right; İsmail Hakk1 Tonguç Belgeliği Vakfı (IHTBV) (İsmail Hakkı Tonguç Archive Foundation). / Hasanoğlan Köy Enstitüsü'nün mevcut genel görünümü (solda; Eken, 2020) ve alanın 1941'deki bozkır görünümü (sağda; IHTBV).

architectural competition, providing the workforce, construction materials, and the construction phases, including the staging, details regarding construction techniques from the foundation to the roofs of the institute buildings, through certain types of buildings where more information about the construction techniques could be understood with narratives of former students and observations on site (Table 1; Figure 4). These types of buildings were mainly workshops (işlikler), schools (derslikler), the dining hall, music complex, country house, and open-air theater. Recent academic studies, and memories of the graduates, former trainers, and students who came to Hasanoğlan from other institutes for work, aerial photos of the institute site since 1948 until today, and old photographs were used as the main sources of the study to create a memory map.

\section{PLANNING PHASE OF HASANOĞLAN VILLAGE INSTITUTE}

Before 1941, 14 village institutes had been established in the Aegean, Black Sea, and Mediterranean regions of Turkey (Figure 1), while establishing a village institute in Ankara was not considered in the original project plan because its political location (Kirby 1967, 217). However, the Second World War posed a threat to the Thrace region, where the Kepirtepe Village Institute was located, so the students there had to be transferred to safer place (Arman 2016, 345). Additionally, creating a center for all institutes was under consideration. Thus, establishment of an institute in Ankara was decided in 1941.

According to the examination report about the institute location, Hasanoğlan Village was approved of based on the existence of a railway, an asphalt road between Ankara and Kirıkkale, and a primary school within the settlement (Figures 5 and 6) (IHTBV); Altunya and Kınac1 2019, 11). As a result of negotiations with peasants, 600 acres of agricultural land, called Hamurbasan was expropriated (IHTBV; Altunya and Kınac1 2019, 12).

Hasanoğlan Village was located west of Ankara, $32 \mathrm{~km}$ away from the city center. The settlement was formed on the outskirts of İdris Mountain in the north. Water resources were abundant within the region, although they have since mostly dried-up. The settlement was located in between Asar (Çet) River in the east and Hasan River in the west. While İdris Mountain was the main source of both rivers, Asar River passed through the settlement and joined Hasan River at the southwestern end of the settlement.

As students from other institutes soon learned that new institute will be opened in Hasanoğlan, some of them notified the Ministry of their willingness to work there voluntarily during the summer. One of whom, Abdullah Özkuçur, former student of Çifteler Village Institute (ÇVI), came to Hasanoğlan in July and was introduced around the village by a friend who once lived there.

According to Özkuçur's observations, the region between Hasan River and the settlement was called Hamurbasan Sirtı by locals who had agricultural land that was irrigated by Hasan River (Figure 7). This area extended to the railway in the south (Özkuçur 2016, 126). Although there was no railway station in Hasanoğlan in 1941, the Lalahan railway station, located $8 \mathrm{~km}$ away, was used for transportation. Another significant area was the stone quarry, located northeast of the settlement between two rivers (Figures 7). This quarry was the main source of construction for the ground floors of the houses in the village (Özkuçur 2016, 125).

Houses in the village were mostly single-storied, but double-storied houses did also exist (Özkuçur 2016, 125). While ground floors were constructed as stone masonry, upper floors were constructed with adobe bricks. There 


\begin{tabular}{|c|c|c|c|c|c|c|c|c|c|c|c|}
\hline Person & $\begin{array}{l}\text { Relation with } \\
\text { HVI }\end{array}$ & 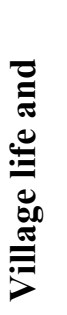 & 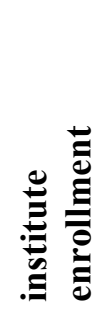 & 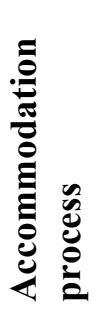 & 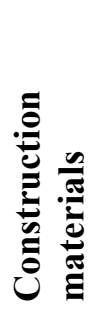 & 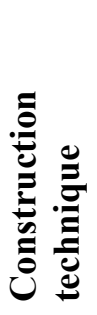 & 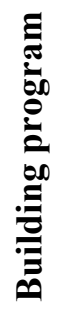 & 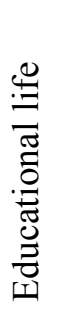 & 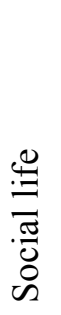 & 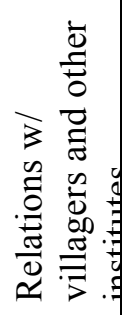 & 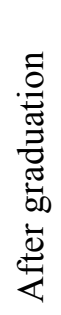 \\
\hline Ali Kınacı & Student & & & + & + & + & + & + & + & + & + \\
\hline $\begin{array}{l}\text { Mustafa } \\
\text { Güneri }\end{array}$ & Student & & + & + & + & + & + & + & + & + & \\
\hline Fakir Baykurt & Student & & + & & & & & + & + & & + \\
\hline $\begin{array}{l}\text { Hürrem } \\
\text { Arman }\end{array}$ & Director & & + & + & + & & + & + & + & + & \\
\hline Recep Bulut & Student & & + & + & + & & + & & + & + & \\
\hline $\begin{array}{l}\text { Süleyman } \\
\text { Koyuncu }\end{array}$ & Student & & & & & & & + & + & + & \\
\hline Vahit Bulut & Student & & & & & & & & + & & \\
\hline $\begin{array}{l}\text { H.Latif } \\
\text { Sarryüce }\end{array}$ & Student & & + & & & & & + & + & & + \\
\hline $\begin{array}{l}\text { Abdullah } \\
\text { Özkuçur }\end{array}$ & Student & & + & + & + & + & + & + & + & + & + \\
\hline Talip Apaydın & Student & & & & + & + & & + & + & & \\
\hline $\begin{array}{l}\text { Halise } \\
\text { Apaydin }\end{array}$ & Student & & & & & & & + & + & & \\
\hline M. Lütfi Engin & Director & & + & + & + & & + & + & + & + & \\
\hline Hidayet Gülen & Student & & + & + & & & + & + & + & + & \\
\hline Ali Y1lmaz & Student & & + & + & + & + & & & + & + & \\
\hline $\begin{array}{l}\text { Mehmet } \\
\text { Akkuş }\end{array}$ & Student & & & & + & + & & & & & \\
\hline $\begin{array}{l}\text { İbrahim } \\
\text { Ayaşlioğlu }\end{array}$ & Student & & & & & & & + & & & \\
\hline $\begin{array}{l}\text { Hasan } \\
\text { Özdemir }\end{array}$ & Student & & & & & & + & & & + & \\
\hline $\begin{array}{l}\text { Hayrettin } \\
\text { Uysal }\end{array}$ & Student & & & & & & + & & & + & \\
\hline $\begin{array}{l}\text { İ.Hakkı } \\
\text { Tonguç }\end{array}$ & $\begin{array}{c}\text { General } \\
\text { Director of } \\
\text { Primary } \\
\text { Education }\end{array}$ & & + & + & + & + & + & + & + & + & \\
\hline
\end{tabular}

Table 1: Distribution of topics within memories about HVI (Menekşe 2005; Güneri 2014; Arman 2016; Baykurt 2016; Özkuçur 2016; Altunya, Kınacı 2019; Apaydın 2020) / Hasanoğlan Köy Enstitüsü hakkındaki anıların konu dağıllmı (Menekşe, 2005; Güneri 2014; Arman 2016; Baykurt 2016; Özkuçur 2016; Altunya, Kınacı 2019; Apaydın 2020) 


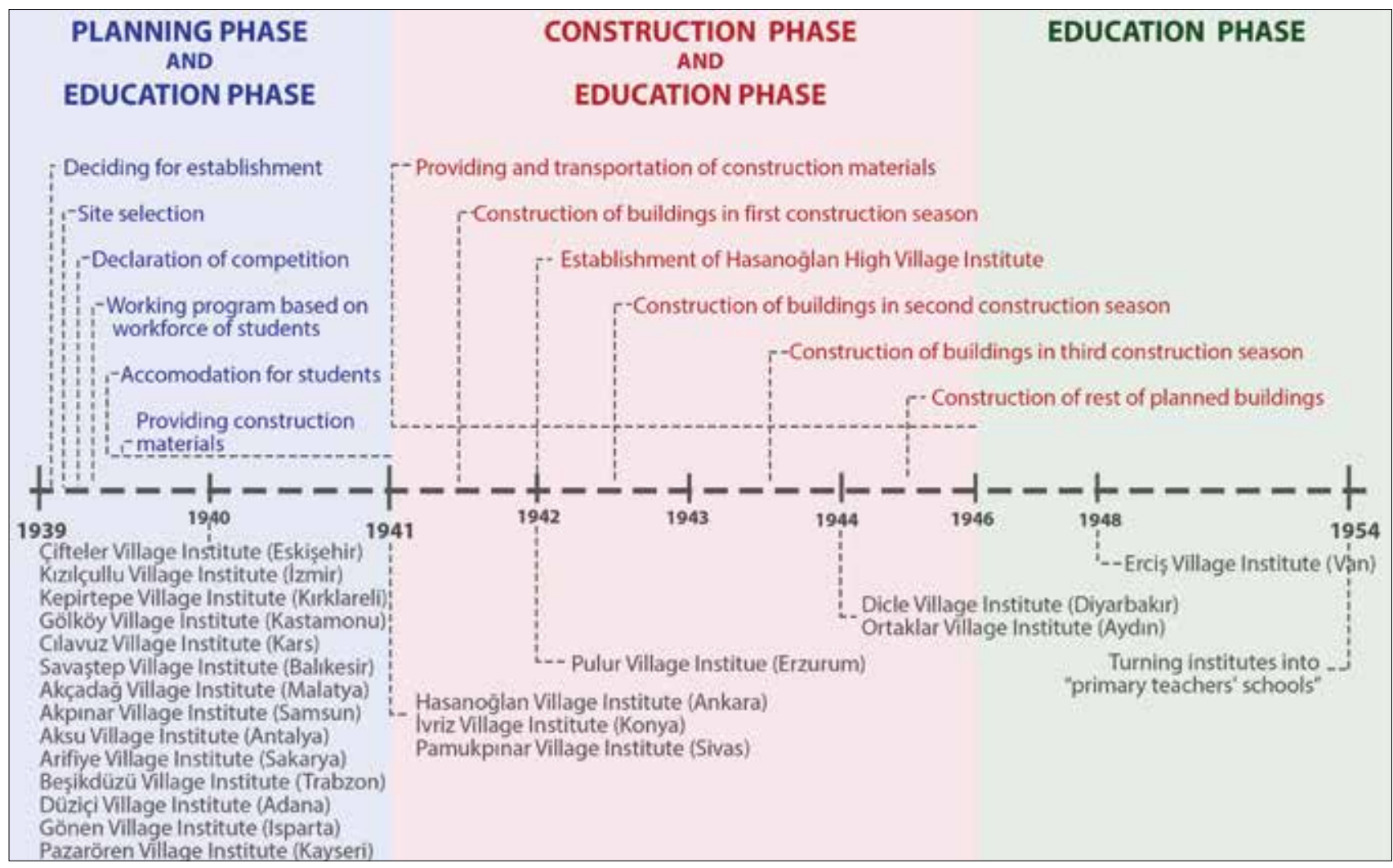

Figure 4: Flowchart of the story of the HVI prepared by the author in 2021 with reference to sources (Menekşe 2005; Çakıc1 and Çorakbaş 2013; Güneri 2014; Arman 2016; Özkuçur 2016). / Kaynakları referans alarak yazar tarafindan hazırlanan, Hasanoğlan Köy Enstitüsü'nün hikayesinin akış şeması (Menekşe 2005; Çakıcı ve Çorakbaş 2013; Güneri 2014; Arman 2016; Özkuçur 2016).

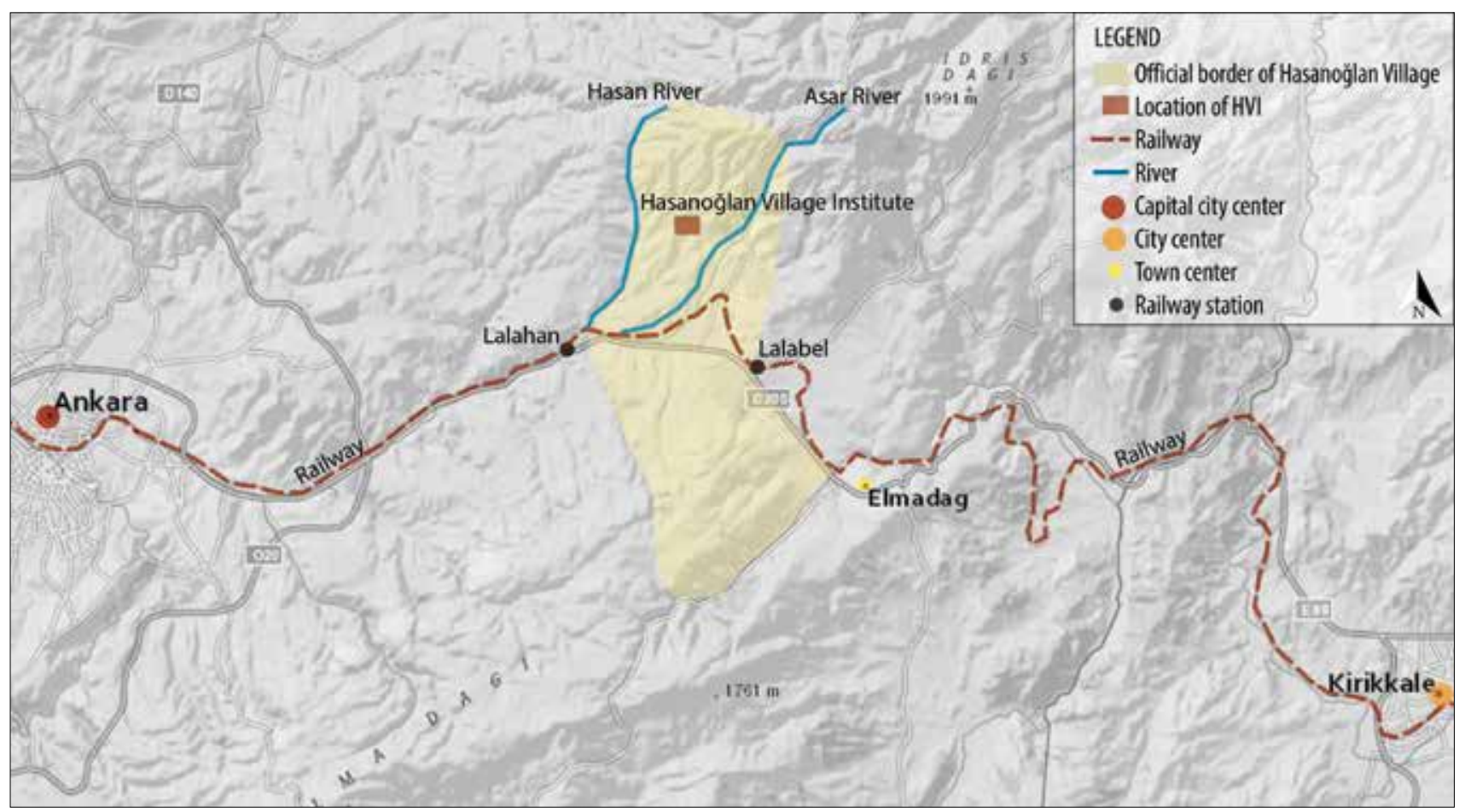

Figure 5: Location of Hasanoğlan Village (Google map, 2020). / Hasanoğlan Köy Enstitüsü'nün konumu (Google Haritalar, 2020) 


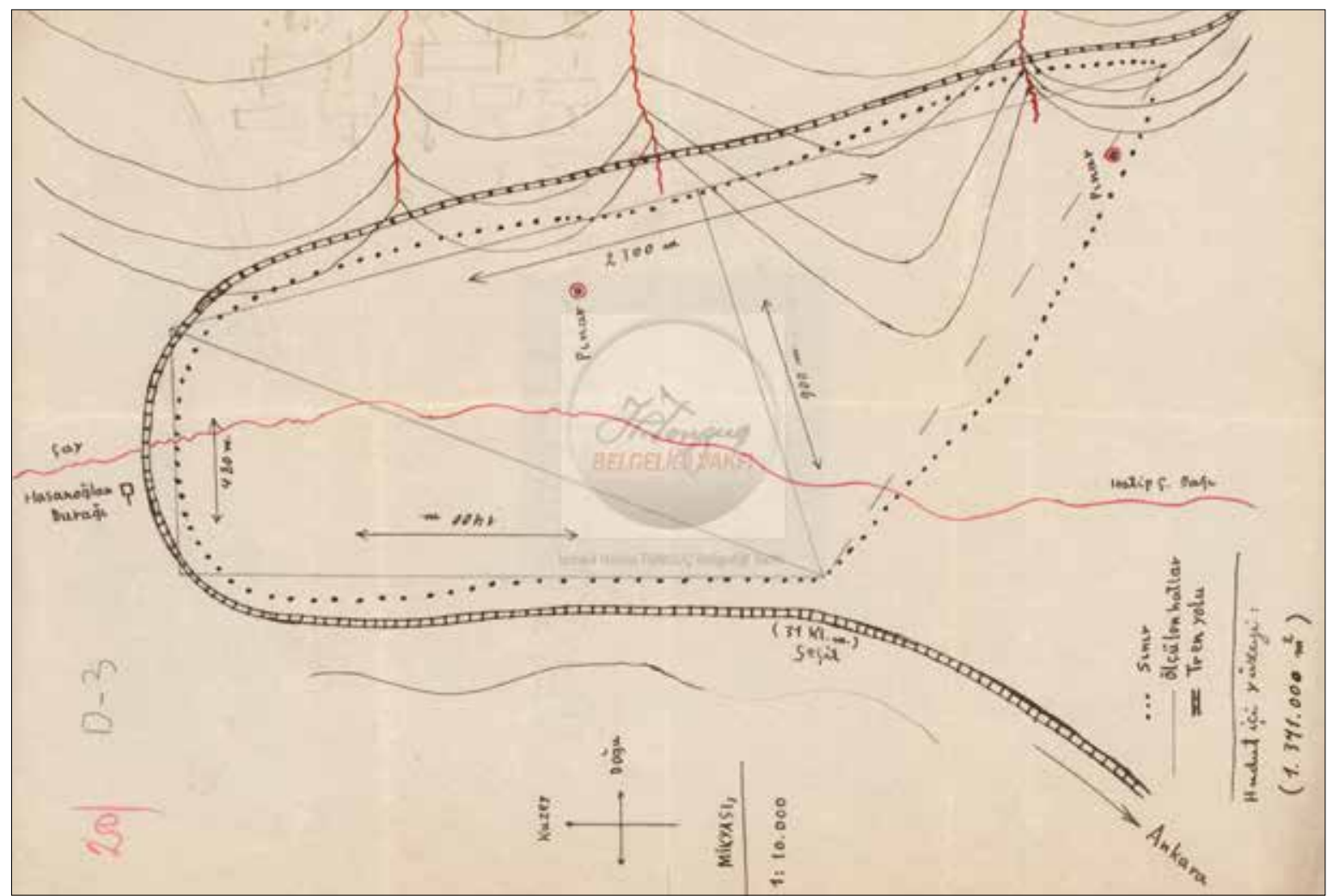

Figure 6: Examination report for Hasanoğlan Village (IHTBV). / Hasanoğlan Köy Enstitüsü için hazırlanmış olan keşif raporu $(I H T B V)$

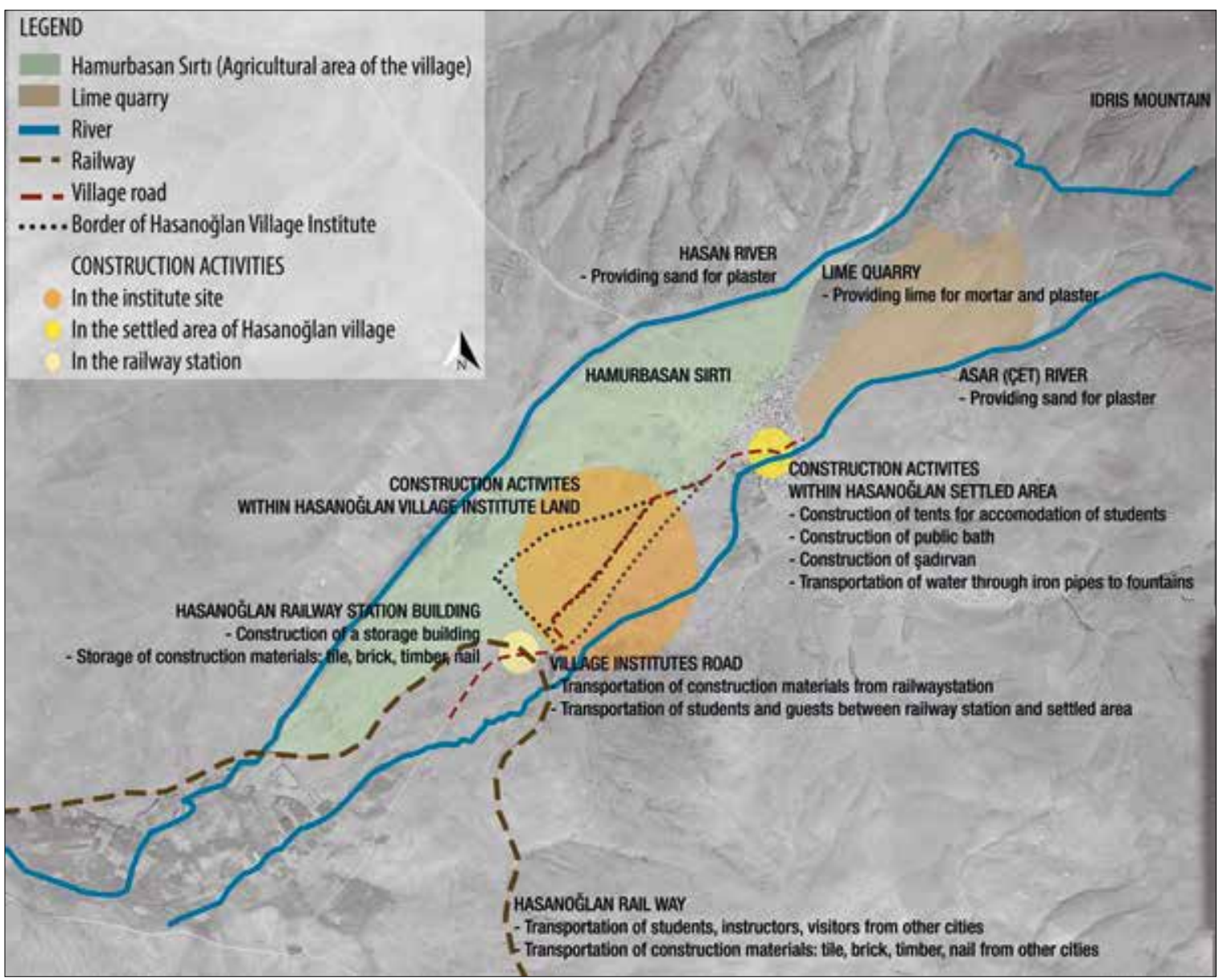

Figure 7: Construction site and significant locations in Hasanoğlan Village on an aerial photo of 1948. / 1948 yll hava fotoğrafi üzerinde Hasanoğlan Köy Enstitüsü’nün inşaat alanı ve önemli alanlar. 
were approximately 250 houses and a population of $\sim 1400$ in 1941. All houses had earthen flat roofs (Figures 8 and 9). Only the mosque and primary school had gable roofs covered with tiles. Özkuçur $(2016,125)$ also emphasize the density of the village:

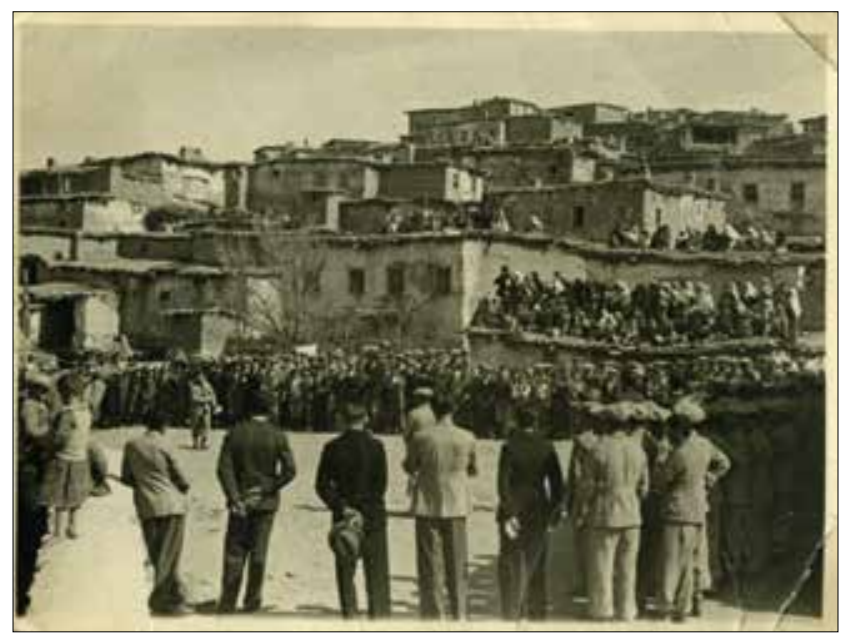

Figure 8: Students, trainers, and peasants in the village square (IHTBV). / Köy meydanında ögrenciler, eğitmenler ve köylüler (IHTBV)

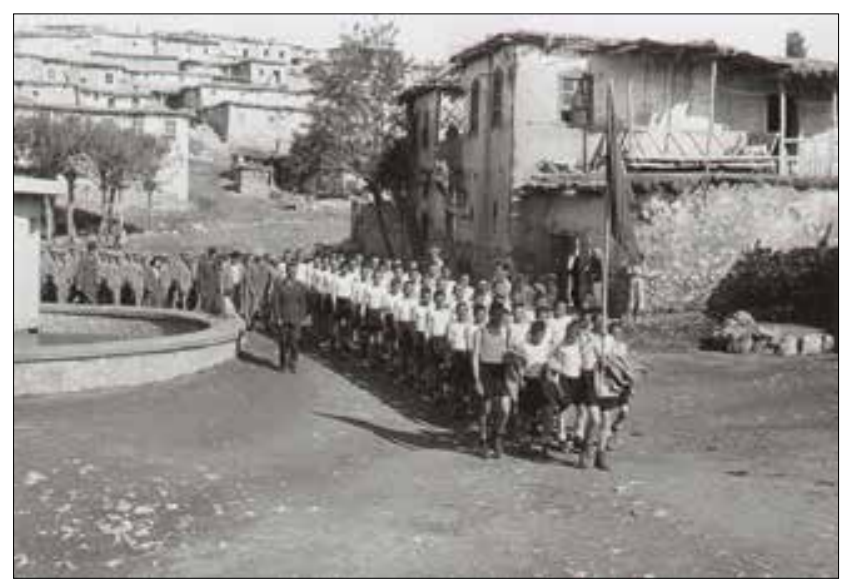

Figure 9: 19 Mayis (19th May) ceremony in the village square (IHTBV). / Köy meydanında 19 Mayıs kutlamaları (IHTBV)

“...Hasanoğlan village is located between Hasan and Çet Rivers. Houses rise step by step, one after the other. It seems possible to wander the roofs of all houses by jumping from one house to another. Houses are so close to each other..."

Like previous village institutes, procurement of an architectural design project for the HVI was determined through an architectural competition (Figure 10). According to specifications of the competition (IHTBV, KLS2_no:60), schools, meeting room, workshop buildings, kitchen, laundry, bath, administrative building, stables, coops, storages, infirmary (revir), toilets and teacher residences are the main type of buildings that should be included in the project. Also, architects should stay in the area where the institute will be established and they should search traditional construction technique and material that can be obtained from surrounding area for construction of institute buildings (IHTBV, KLS2 no: 60$)^{1}$.

As a result, the project of Kemal Ahmet Aru, Orhan Safa, and Adnan Kuruyazıcı was approved on 4 July 1941 (Dönmez 1945, 22). The site plan included schools, workshops, dormitories, teacher residences, administrative building, toilets, storage buildings, stables, coops, a kitchen, meeting hall, laundry and bath, exhibition hall and museum, infirmary, and playgrounds (Çorakbaş 2013, 324; IHTBV). Considering the locations and functions of these buildings, the site plan consisted of different functional zones, like educational, residential, social, and husbandry zones, and agricultural land (Figure 10).

After determining the location and plan for the institute, a working program was formed, and the project was implemented. The Ministry of Education sent a statement to 14 village institutes emphasizing participation by 30 people (20 students, 10 trainers) from each institute in the Hasanoğlan construction process. Additionally, Mustafa Güneri was appointed as the structure-art branch president (yapl-sanat kolu basskanl) and acting director of coordination for the construction. In addition to Güneri, Sili Layoş, Gaspar Anyipal, Gabel Mihaly and Mualla Eyüboğlu are experts frequently mentioned in former students' memories (Menekşe 2005; Özkuçur 2013; Güneri 2019; Apaydın 2020).

Among the experts that have participated the construction process of HVI, Sili Layoş, Gaspar Anyipal and Gabel Mihaly are Hungarian specialists employed as part of the modernization movement during the Republican Era. According to the archive documents (Yildirim 2012, 126129), approximately 170 Hungarian experts have been employed in various type of government agencies in the first 25 years of Republican Era. These documents also show that three Hungarian experts have been employed in the construction process of 18 village institutes with the decision of the Council of Ministers No. 3/1256 on 21 July 1944 (Çolak 2004, 241)2. In addition to these

With the Village Schools and Institutes Organic Law (act numbered 4274) in 1942, it is guaranteed that no fee is charged for the materials to be obtained from the surrounding of construction sites and that the relevant government institutions provide free materials.

These institutes are Kepirtepe (Kırklareli), Arifiye (Kocaeli), Kızılçullu (İzmir), Savaştepe (Balıkesir), Gönen (Isparta), Aksu (Antalya), Çifteler (Eskişehir), Düziçi (Adana), 


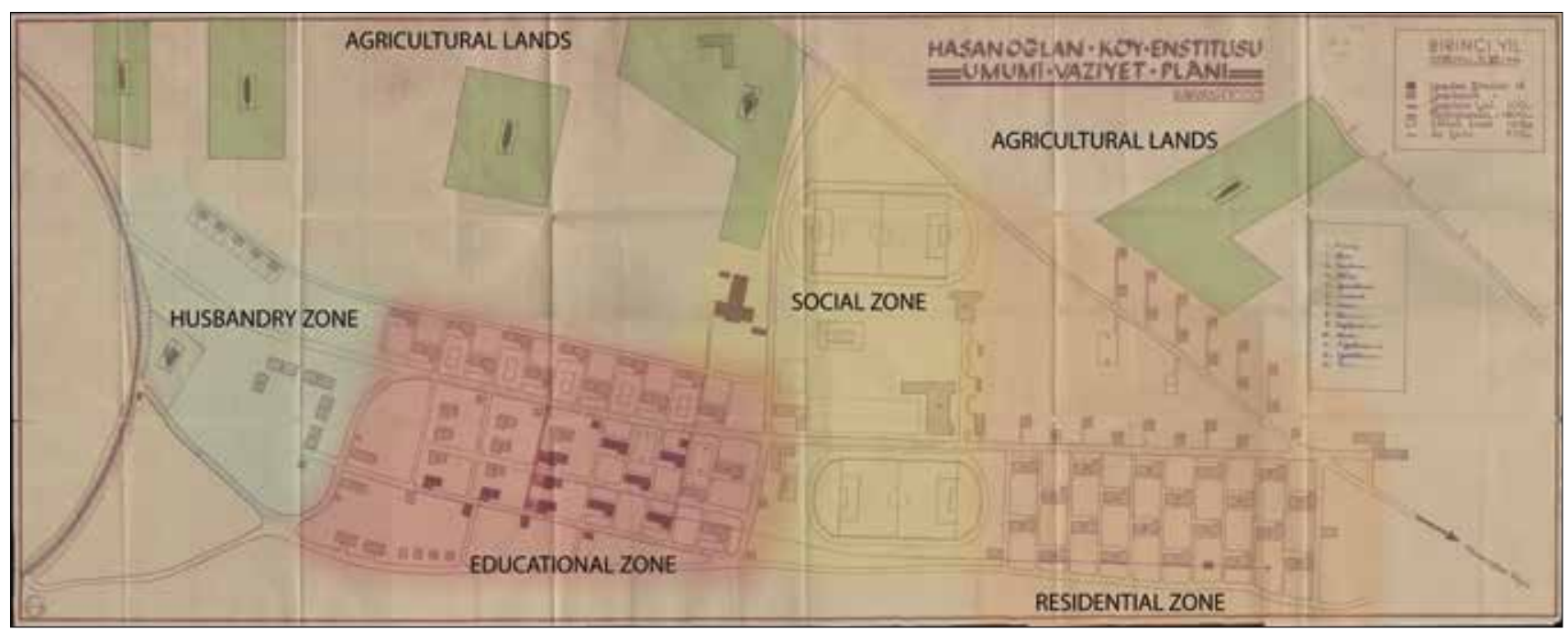

Figure 10: Site plan of the winning project (colored by the author based on archive documents obtained from IHTBV; yellow: social zone, red: educational zone, orange: residential zone, blue: husbandry zone and green: agricultural zone). / Kazanan mimari projenin vaziyet planı (IHTBV'ndan elde edilen arşiv dokümanlarına göre yazar tarafindan renklendirilmiştir; sarı: sosyal alan, kırmızı: eğitim alanı, turuncu: konaklama alanı, mavi: hayvancılık alanı ve yeşil: tarım alanı)

experts, Mualla Eyüboğlu, a master architect, participated voluntarily for the first time in the construction process of the HVI. Then, she also participated in the planning phases of future institutes (Gurallar 2017).

The first-year construction program, covering the summer and autumn, was based on a month work of five different institute groups (Güneri 2019; Figure 1). As an exception, the first group included all students/ trainers from Kepirtepe Village Institute due to the threat of war in the Thrace region. Other groups were formed as follows: Ladik (Samsun), C1lavuz (Kars), and Pazarören (Kayseri) Village Institutes constituted the second group; Gölköy (Kastamonu), Akçadağ (Malatya), and Düziçi (Adana) constituted the third group; Beşikdüzü (Trabzon), Gönen (Isparta), and Aksu (Antalya) Village Institutes constituted the fourth group; Arifiye (Sakarya), Savaştepe (Balıkesir), and Kızılçullu (İzmir) Village Institutes constituted the fifth group to work at the Hasanoğlan construction site in the first season (KEÇEV 2003, 244; Menekşe 2005, 157; Özkuçur 2013, 23; Güneri 2019, 3-5).

As the students from Kepirtepe arrived in Hasanoğlan Village, the first issue was arrangement of accommodations for guest students. Recep Bulut, a graduate from Kepirtepe, stated that while some students settled into the mosque and primary school in the village, tents were established within the courtyard of the primary school for the rest (Figures 11 and 12; Menekşe 2005, 156). A foundation building around the village square was transformed into kitchen and wooden

Pazarören (Kayseri), Akpınar (Samsun), Beşikdüzü (Trabzon), Cılavuz (Kars), Akçadağ (Malatya), Gölköy (Kastamonu), İvriz (Konya), Yildizeli (Sivas), Pulur (Erzurum) and Dicle (Diyarbakır) (Çolak 2004, 241).

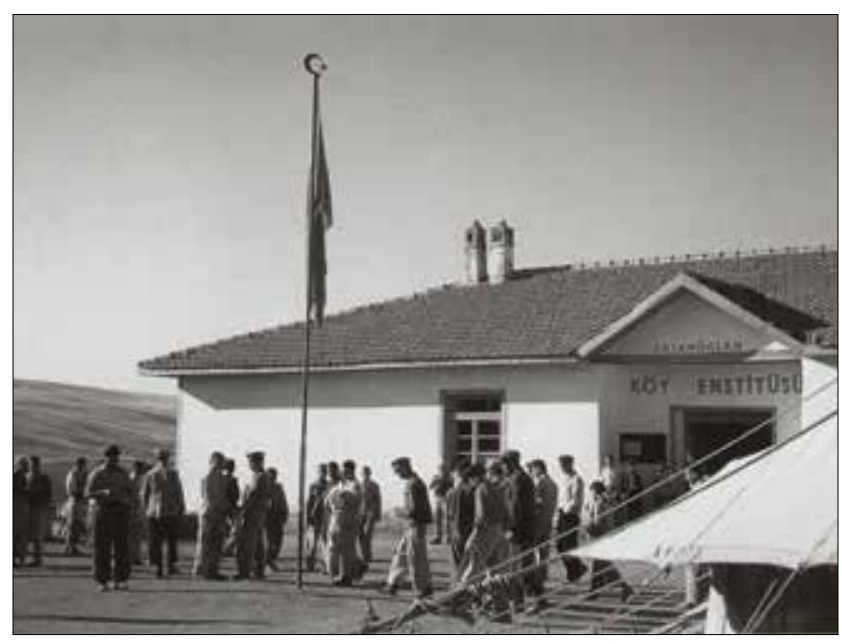

Figure 11: Temporal transformation of the village primary school into an institute building (IHTBV). / Köy ilkögretim okulunun geçici olarak enstitü binasına çevrilmesi (IHTBV)

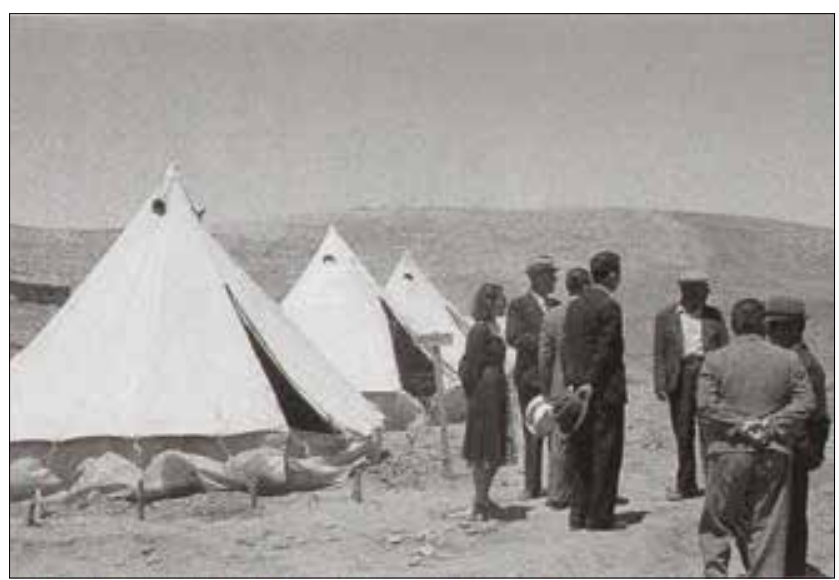

Figure 12: Tents for trainers in the primary school garden (IHTBV). / İlköğretim okulunun bahçesine eğitmenler için kurulmuş olan çadırlar (IHTBV) 

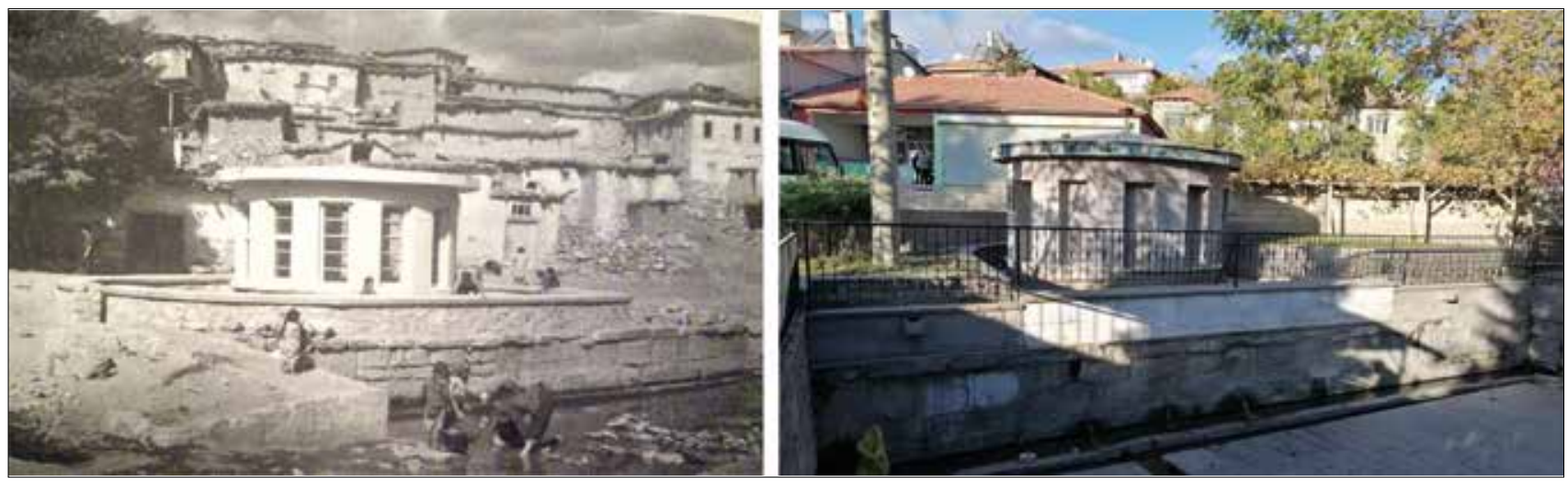

Figure 13: Şadırvan in 1941 (left; Güneri 2016, 16) and 2020 (right; Eken 2020). / Şadırvanın 1941 yllındaki (solda; Güneri 2016, 16) ve 2020 yllındaki (săgda; Eken 2020) görünümü

tables were constructed by the villagers for eating and studying (Güneri 2019, 1). Additionally, two village houses were rented and used temporarily as iron and timber workshops (Özkuçur 2016, 139).

Due to the increased population in the village, spring water in the village square was inadequate. Additionally, temporary accommodations in the primary school made it necessary to find an alternative water source. A fresh spring was discovered around the Beşkavak region, located $3 \mathrm{~km}$ away from the village. Water was transported through iron and earthen pipes under the direction of Hungarian expert, Sili Layoş (Özkuçur 2016, 152).

During these studies, three students from ÇVI, Abdullah Özkuçur, Ali Yılmaz, and Niyazi Baykal, also participated to working team. They were experienced in construction, and they constructed a water storage (şadırvan) above the spring water in the village square, which was the main water source (Figure 13). Additionally, they constructed the roof of the laundry building, whose walls were built by students of Kepirtepe, and a public bath in the village square with master trainer, Mehmet Yurtkuran (Özkuçur 2016, 152).

Şadırvan still exists, although its windows of şadırvan are fully closed, and the laundry and bath buildings are lost at present (Figure 13). However, the construction technique for the public bath can be deciphered through the inscription panel on the şadırvan. The narratives of three students stated that the walls were made of stone, and it had a reinforced concrete roof slab. Due to a lack of iron, wire-mesh fence was hammered on both sides of the densely laid timber rafters and a cement mortar was poured between the rafters.

\section{PROVIDING BUILDING MATERIALS FOR HVI}

Another significant issue in the planning phase was providing construction materials. As with other post-
1941 institutes, local sources were most effective solution for the HVI due to the economic depression (Kirby 1962, 208).

First, water from şadırvan in the village square was transported to the construction site through an earthen pipe waterway due to difficulties in transporting water (Figure 14; Güneri 2019, 2). Additionally, temporal wooden workplace and storage buildings were constructed, and lime pits were drilled within the construction site (Menekşe 2005, 156).

In terms of construction materials, stones were removed from the stone quarry located north of the settlement. According to Özkuçur $(2016,135)$, after breaking rocks into pieces using dynamite and sledgehammers, stones were transported to the construction site using tumbrels or wheelbarrows (Figure 15). The sand for mortar and plaster was obtained from stream beds of Hasan River in the west and Asar River in the east (Güneri 2019,2).

In addition to local materials like lime, brick, tile, and timber; contemporary materials like iron, cement, and nails were also necessary to construct buildings. Güneri (2019) stated that no lime or brick quarry existed within the village of Hasanoğlan. Thus, lime was bought from quarries in Küçük Yozgat, called Elmadağ today. Although Güneri (2019) stated that brick and tile were obtained from Eskişehir, Talip Apaydın (2020, 21), a former CVI student, emphasized that intense brick production existed at ÇVI, established in 1940, and the bricks were also have sent to other institutes. Thus, the brick used in Hasanoğlan may have been produced by students at ÇVI.

Apaydin $(2020,21)$ reported production process of the bricks: 


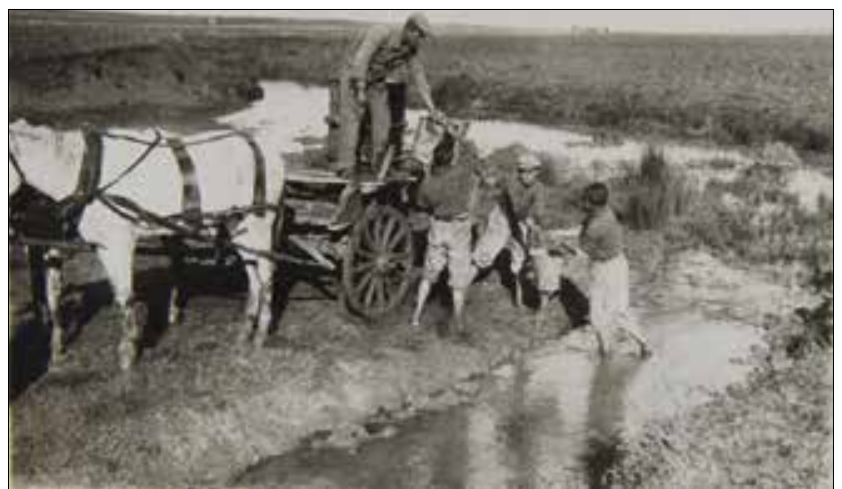

Figure 14: Transporting water from the river to the construction site in buckets before establishing the water canal (IHTBV). / Su kanalı inşasından önce nehirden inşaat alanına kovalarla su taşınması (IHTBV)

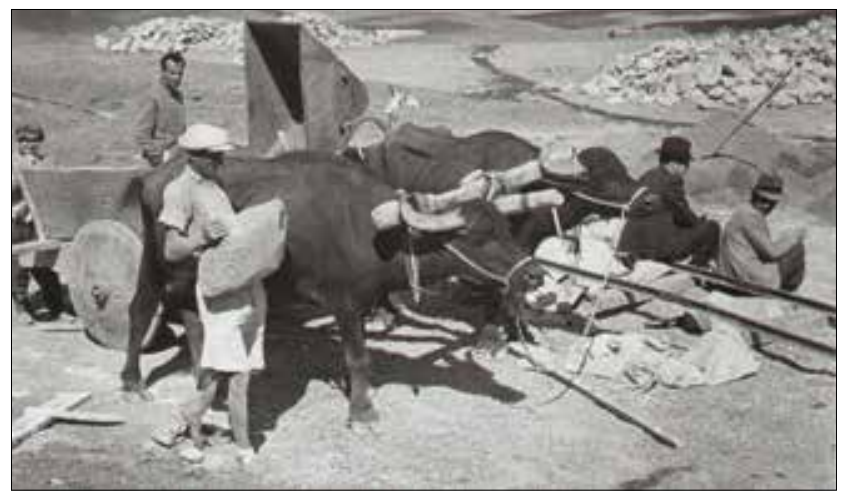

Figure 15: Transportation of stones to the construction site (IHTBV). / İnşaat alanına taşların taşınması (IHTBV)

“...Our friends, who cut the mud at the counter and fill it into molds, would be a kümebaşl. This was the main work that required mastery. An old and experienced person would sit at the counter. He should have managed three or four molders at once. We, little students, were always mold makers. We would run the mold filled by the master, empty it and bring it to the field properly, without breaking it. We were like fleas. It was forbidden to make the master wait a little bit. It was our duty to clean the inside of the mold with a special knife, to sand or wet it every time so that the mud would not stick, and to pour the molds in rows..."

After bricks were left to dry, stacked on top of each other to allow air flow through them. Finally, they were baked at a high temperature (Figure 16). Quarries were located under the ground and access was through a ditch (hendek). Apaydın $(2020,22)$ emphasized:

“...Dry grass or straw had to be thrown into the fired stove with a pitchfork without stopping. If there was a break, the bricks would be broken...You had to swing the pitchfork from the back and fill the fire in order not to stop the fire. The fire of the stove, on the one hand, the hot sun above your head, on the one hand, the person would become roasted..."

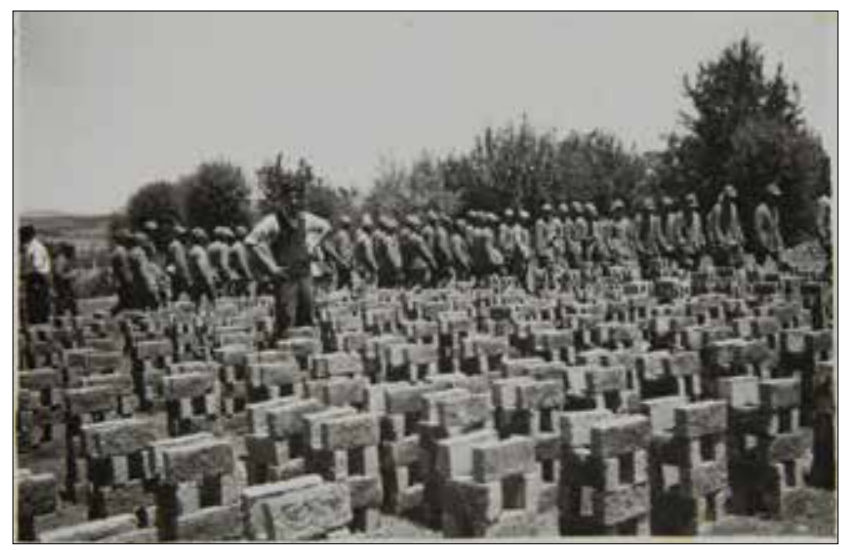

Figure 16: Brick drying process at an institute (IHTBV). / Enstitüde tuğla kurutma aşaması (IHTBV)

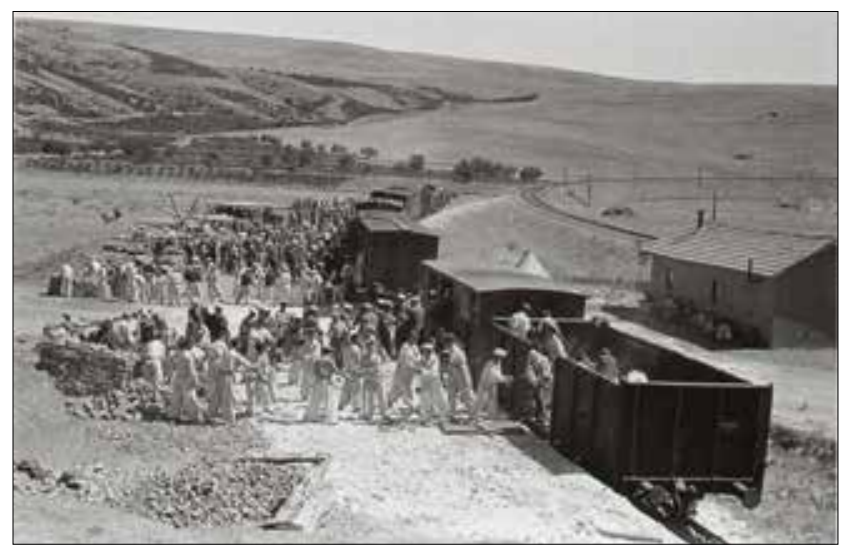

Figure 17: Transferring bricks at Lalahan Railway Station (IHTBV). / Tuğlaların Lalahan Tren İstasyonu'ndan transferi (IHTBV)

Although Apaydın supplied no information regarding the production of tile, Kınac1 stated that tile was also produced by students at ÇVI. During which time, molds supplied from a factory in Eskişehir were used (Figures 16 and 17).

Timber elements were necessary for roof construction and architectural elements like doors, windows, and tables. These elements were obtained from Beypazarı (Ankara), Sakarya (Arifiye Village Institute), Karabük, and Kırıkkale, respectively (Güneri 2019, 2). However, the timber species ordered for architectural elements varied according to the aim of usage. While Arman (2016, 361) stated that pine was obtained from Beypazarı for architectural elements, Güneri $(2019,2)$ claimed that the Arifiye Village Institute sent a fair amount of hornbeam (gürgen) wood to use as lintels especially.

In accordance with the Organic Law of Village Schools and Institutes (Köy Okulları ve Enstitüleri Teşkilat Kanunu, Law No. 4274), forest administrations should provide a certain amount of forest products to village institutes at a certain fee. However, this law only came into force in 1942. Thus, obtaining affordable timber 
for Hasanoğlan was a problem. Hürrem Arman, director of Beşikdüzü Village Institute between 1940 and 1943, had an active role in obtaining timber (Arman 2016). According to negotiations between Arman and forest engineers in Beypazarı, Ankara; wood would be turned into roundwood in forest areas. Then, the dimensions of the architectural elements to be established would be determined in Hasanoğlan by the students and trainers. Finally, all wooden elements of certain sizes would be delivered, to be unloaded at Lalahan Station. The fact that the wood was brought from Beypazarı for a low fee also resulted in complaints to the Ministry of Finance by timber merchants around Hasanoğlan about materials being purchased illegally. The problem was solved through an official statement by the Ministry of Education and Directorate of HVI (Arman 2016, 362).

Despite of the introduction of iron and cement into the construction sector in Turkey at the beginning of the $20^{\text {th }}$ century, these materials were the most difficult to obtain during the 1940s due to the economic crisis. However, portable railways and iron bars could be obtained from scrap dealers in Ankara. Additionally, while some cement was bought from the Ankara Cement Factory, nails were ordered from İstanbul for a certain fee under the agreement provided by the Ministry of Education (Güneri 2019, 2).

Due to the lack of a railway station in Hasanoğlan, all ordered construction materials were unloaded at Lalahan Station, located $7 \mathrm{~km}$ from the village. Bulut, a student from Kepirtepe Village Institute, stated that after unloading, the materials were transported to the construction site in trucks, tumbrels, and wheelbarrows. Transportation was performed by different student groups in shifts, during which the students stayed at an adobe masonry house near the station to keep the materials safe (Menekşe 2005, 156).

\section{CONSTRUCTION PHASE OF HASANOĞLAN VILLAGE INSTITUTE}

Because of the harsh climatic conditions during winter in Ankara, summer and autumn comprised the construction season of the HVI. In light of the memories and archive documents, the construction process was examined at 5-time intervals, comprising 1941, 1942, 1943, 1944, and 1944 until its closure (Figure 18).

The first-year construction program began on 9 July 1941 with foundation pit preparation for the first building (Güneri 2019, 24). Under instruction by trainers like Mualla Eyüboplu and Mustafa Güneri, students hammered stakes and stretched ropes between them according to the building plan. According to Özkuçur
(2013, 137) and Güneri (2019, 24), on 10 July 1941, all students, and trainers in the first group came to the construction site with drums, flutes, and flags in-hand, and gathered around the foundation pit of the workshop building that will be constructed by the students from Pazarören. A pickaxe was used in the groundbreaking ceremony by Ferit Oğuz Bayır, The Deputy General Manager of Primary Education; hence, the construction process officially began.

According to the memories, the first-year program was based on construction of a toilet, six workshops for practical education, four storages for workshops, six schools for theoretical education, a dining hall, and a switchboard across from the dining hall (Figure 18). Additionally, after constructing the switchboard, poles were established and lines between them were installed (Güneri 2019, 59). Thus, along with the institute, the village also gained electricity. Moreover, due to difficulties on the site at the beginning of the rainy season, all roads between the completed buildings were covered with crushed stones (Güneri 2019, 89).

In parallel with the construction, agricultural work also began at the end of the first year. Barley and wheat were planted in the expropriated fields, and tree planting began by trenching the land, locally known as kirizma (Figure 19; Güneri 2019, 60).

In 1942, a dormitory and ten instructor's houses within the residential zone were constructed, in addition to two schools within the educational zone, a coop, and a stable close to the railway in south. In the third construction season, another dormitory and another toilet within the residential zone, a workshop within the educational zone, an administrative building, a large timber workshop, a mixed workshop, including a switchboard and tailor workshop, a large iron workshop, two garages for vehicles, an open-air theater, and a music hall, added to the original plan by Mualla Eyüboğlu, were constructed (Figure 18). In addition to the continuing construction process, hundreds of fruit and non-fruiting trees were planted and vegetable cultivation began under the guidance of İzzet Palamar, tarımbaşı (head of agricultural works), until the end of 1942 (Figure 19).

Although the Department of Higher Institute was established in 1942, the high institute building could be constructed in the 1944 construction season. Additionally, another dormitory, bakery, storage building for food, and a complex, including laundry and bath, were constructed in that period (Figure 18). Finally, after 1944, three dormitories and an instructor's house within the residential zone, three guest residences close to railway, three storages, a practicing workshop, country 


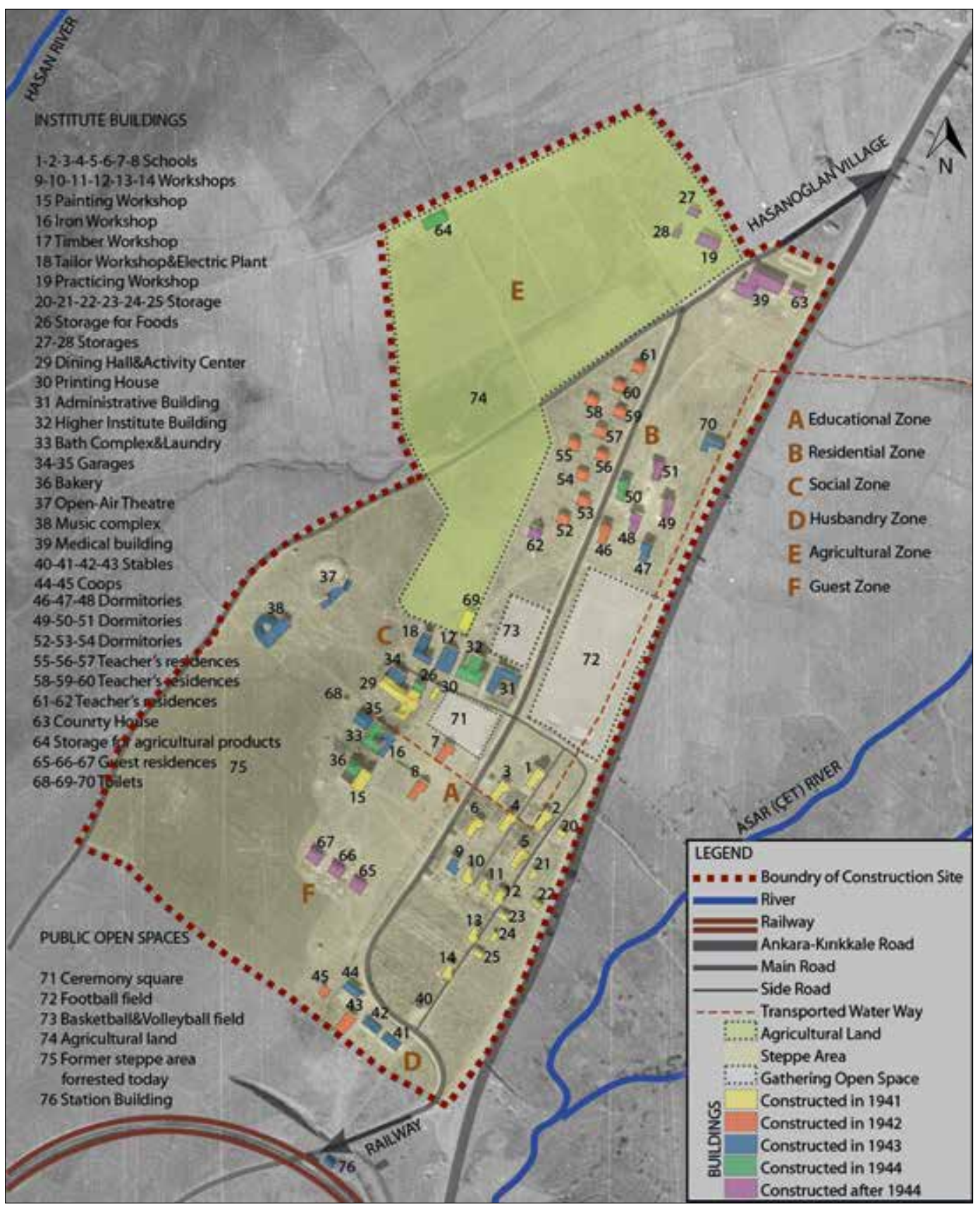

Figure 18: Spatial memory map of the institute site on a 1948 aerial photo (prepared by the author in 2021 with reference to information given by Güneri 2019, p.20; IHTBV). / 1948 yılı hava fotoğrafi üzerinde hazırlanmıs mekânsal hafiza haritası (yazar tarafindan 2021 yılında Güneri'nin 2019, 20 çalışmast ve IHTBV arşiv belgeleri referans alınarak hazırlanmıștır.)

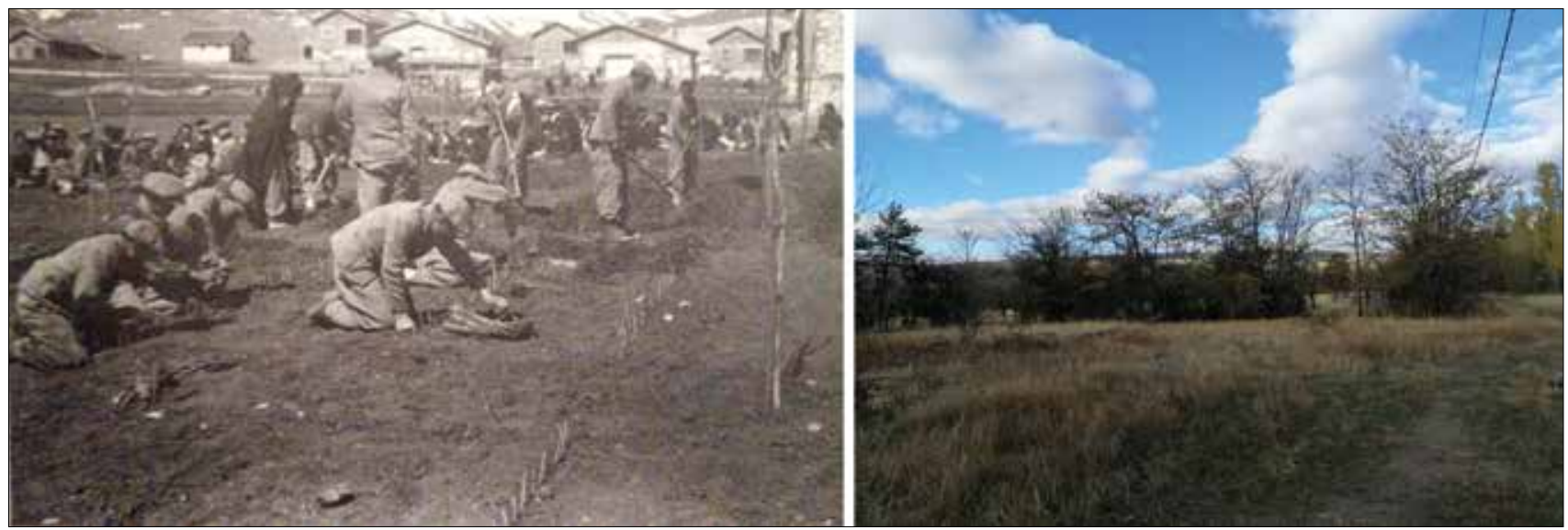

Figure 19: Cultivated area in 1942 (left; Güneri 2019, 107) and presently (right; Eken 2020). / 1942 yllında tarım alanlarl (solda; Güneri 2019, 107) ve güncel görünümü (să̆da; Eken 2020) 
house close to the agricultural lands, and infirmary (revir) on the village road were constructed in the north (Figure 18). Among these buildings, much information regarding construction techniques for the buildings from the foundation to the roof could be deciphered through memories related to the construction of workshops, schools, dining hall and music complex roofs, and openair theater (KEÇEV 2003, 252; Menekșe 2005, 157; Özkuçur 2013, 24; Güneri 2019, 22).

The first phase of the construction process was drawing the plan on the ground and determining the corners using piles. Özkuçur $(2016,140-141)$ explains the construction process of a school he built with his other friends from Çifteler Village Institute as follows:

“...We got the plan of the school we will do from Mustafa Güneri, the head of the building arts. We learned the location of the school from the expert, Sili Layos... We arrived at work area early in the morning. We stretched the ropes. First, we started the excavation for construction of basement floor... As the excavation progressed, stretchers and wheelbarrows were insufficient to carry the soil away. Portable railways were laid in this part of the construction site. Railway crates were placed on the rails. Transportation of soil turned out to be a very enjoyable work..."

During excavation, while one group of students carried the stones and bricks to the excavation site, another group prepared mortar in large cauldrons. They sifted sand, quenched lime, and mixed it with cement and water in certain quantities under the direction of the masters to obtain mortar (Figures 20 and 21; Özkuçur 2013, 23). According to old photographs, these works requiring little manual effort were usually done by female students (Figure 21).

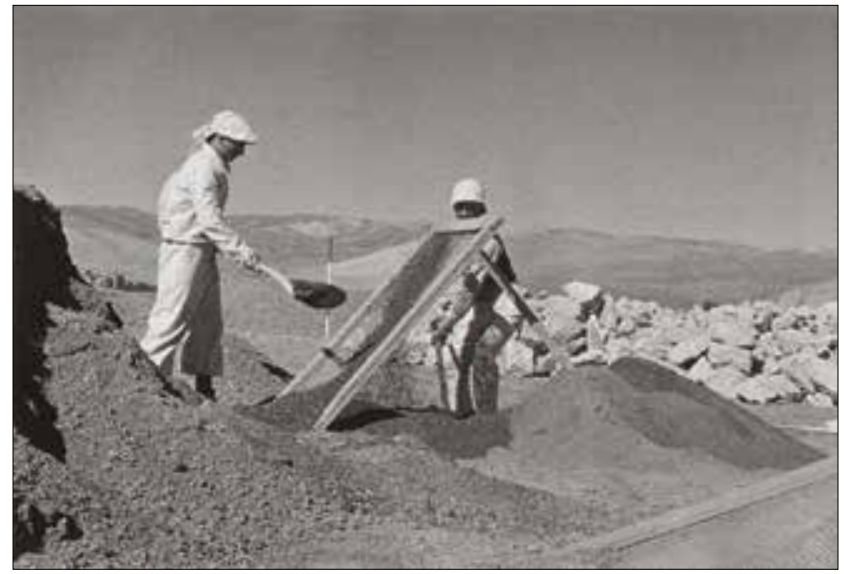

Figure 20: Sifting sand for mortar preparation (IHTBV). / Kireç söndürme aşaması (IHTBV)

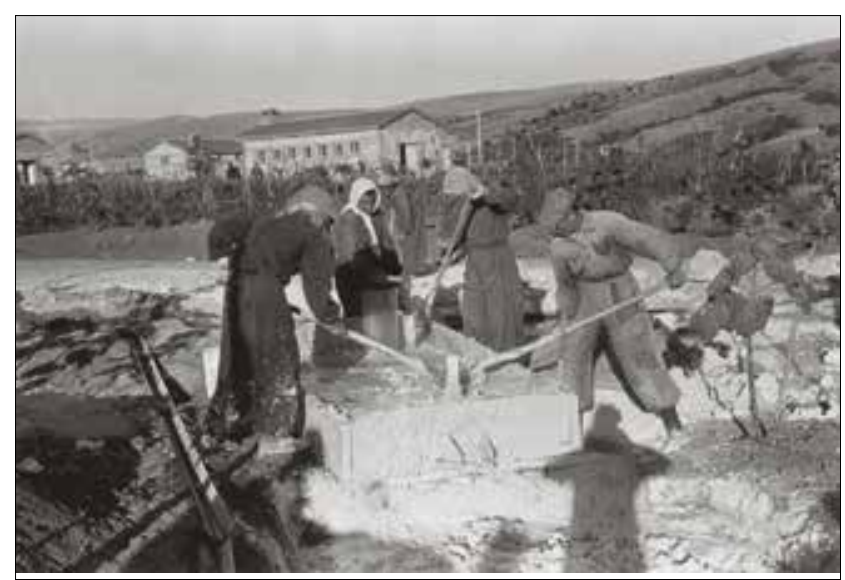

Figure 21: Quenching lime process (IHTBV). / Harç hazırlanması için kumun elenmesi (IHTBV)

After excavation, the pit was filled with large stone blocks forming foundation walls and blinding concrete was poured on the ground level where the foundation walls were in contact with the soil surface. Akkuş, a former student of Akpinar Village Institute, explains the wall construction process of the building as follows (Özkuçur 2016, 153):

“...First, we build the wall with stone up to a certain height (approximately 1 meter according to the observation on site), then we move on to brickwork. Using plumb, we determine the two corners of the wall. We pull two ropes opposite each other. We are preparing the place of the stone that we will put on the wall. Then, we trim stone surfaces using hummer (locally called madirga) and set it in place so that you cannot move it even if you want (Figure 22). Next, we avoid putting the stone vertically. We put moderate mortar between the stones, neither less nor more. We try to keep the stone from touching the ropes. If we become distracted and the stones touch the rope, Sili Layos comes and stops our work..."

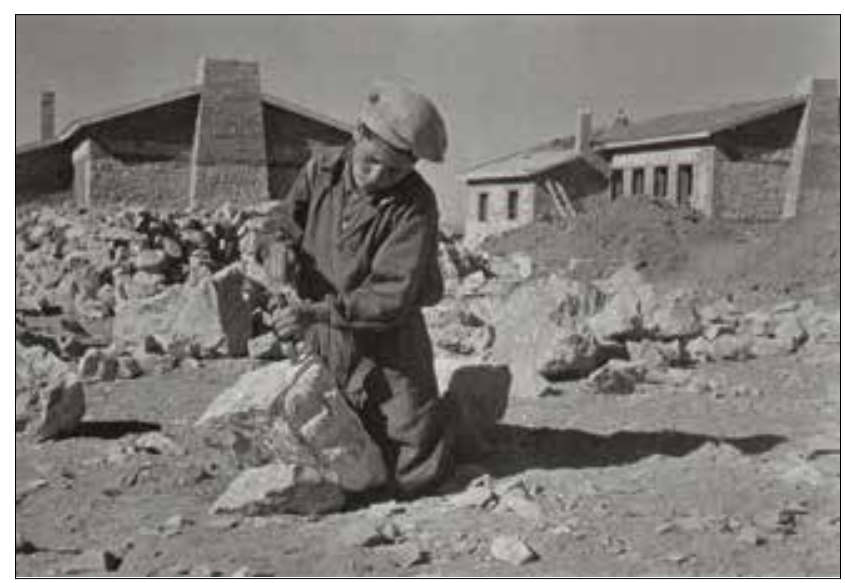

Figure 22: A student trimming a corner stone (IHTBV). / Köşe taşını düzenleyen bir öğrenci (IHTBV) 
Apaydın (2020,51), a former student of ÇVI, also emphasized that corner stones were established by master students using plumbs and small stones and mortar was filled between the big stones in the foundation construction.

Old photographs of the construction process show that exterior walls without any openings were constructed using stone masonry, as well as two rows of brickwork at regular intervals of $\sim 1 \mathrm{~m}$. The exterior walls, which had openings and gable walls, were constructed with brick. Apaydin $(2020,51)$ stated the construction of a stone masonry building took $10-15$ days, while that of buildings with brick walls took 5-10 days (Figure 23). During wall construction, chimneys were also constructed with bricks using wooden molds (Güneri 2019, 54).

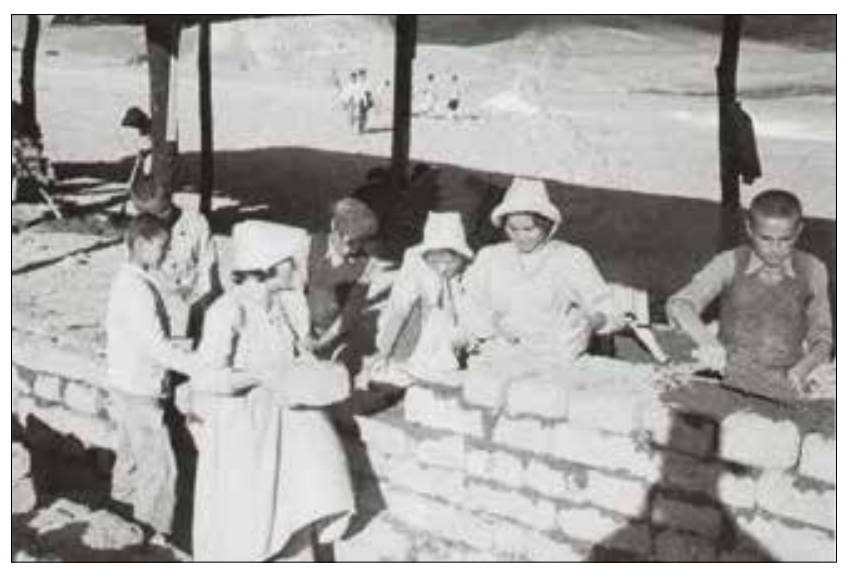

Figure 23: Construction of a brick wall above stone masonry (IHTBV). / Yığma taş duvar üzerine tuğla duvarın inşa edilmesi (IHTBV)

While the single-story workshops that were constructed in the southeastern part of the site, which no longer exist, did not require flooring, the double-story buildings, such as schools located north of the workshops, did require flooring. According to Özkuçur (2016, 138), these L-shaped schools had a basement floor use as a temporarily refuge, and the floor of the groundfloor was constructed with reinforced concrete. In this process, iron bars were reshaped by students in the iron workshops. During the site survey, details regarding the reinforced concrete were observed in the roof slab and dome of the bath complex (Figures 24 and 25). Despite the dense material deteriorations, some schools and bath complexes still had their authentic characteristics.

After completing the wall construction, gable roofs were generally constructed using timber transported from the station through the established portable railways. Özkuçur $(2016,138)$ stated that the triangular timber forms were created first on the ground, and then traced-

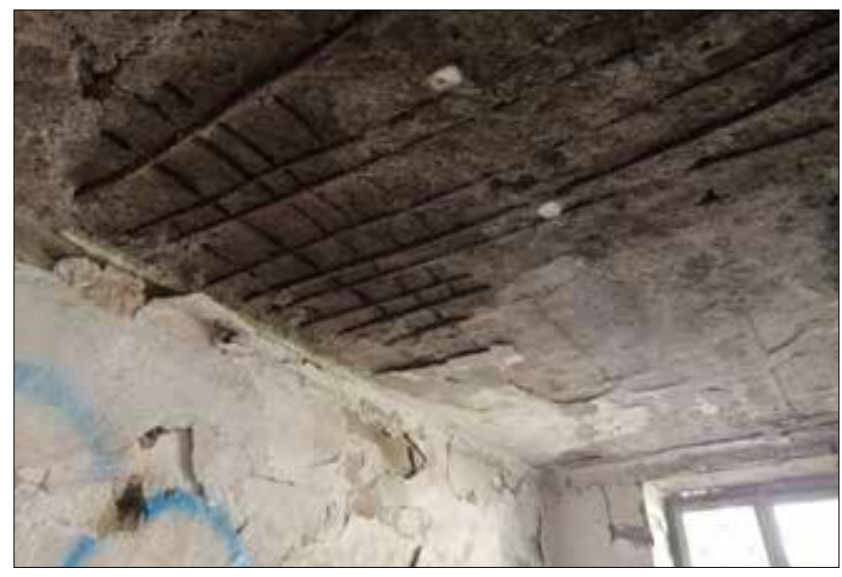

Figure 24: Roof slab (soğukluk) in the bath complex (Eken 2020). / Hamam yapısında soğukluk mekânı üzerindeki tavan döşemesi (Eken 2020)

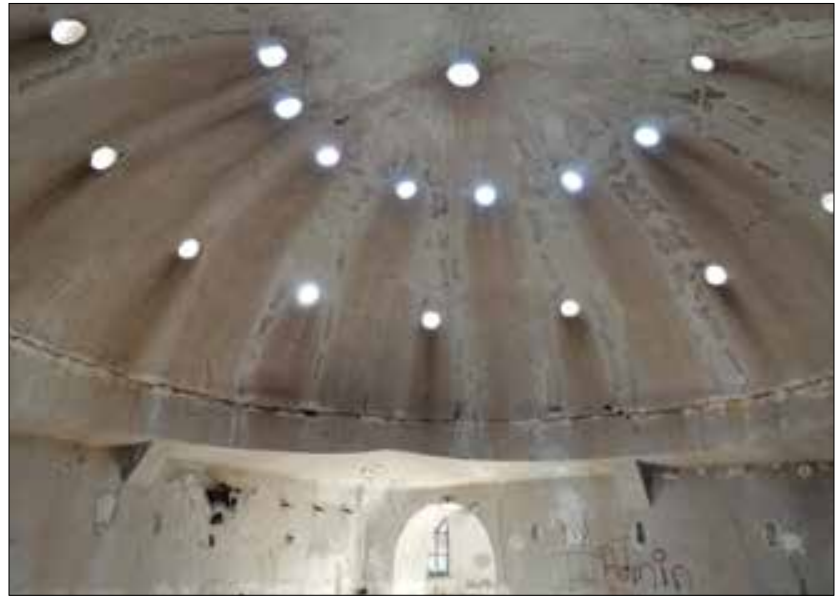

Figure 25: Dome (sicaklık) in the bath complex (Eken 2020). / Hamam yapısında sıcaklık mekânı üzerindeki kubbe (Eken 2020)

up onto the walls (Figure 26 and 27). Finally, groundwork for the roof was completed and the roof was covered with Marseille tiles.

Unlike most buildings with gable roofs, the roof of the dining hall, located in the middle of the site and attached to the activity center, was constructed with a

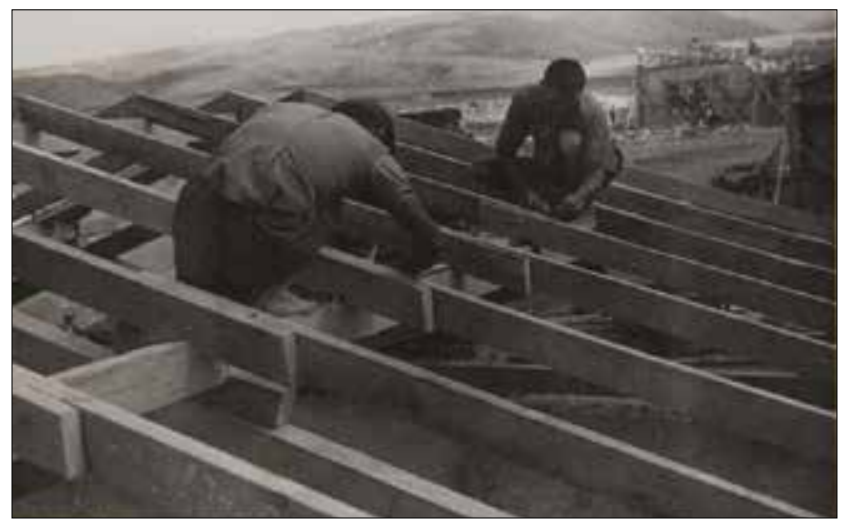

Figure 26: Roof construction details (IHTBV). / Çatı inşaatı detayı (IHTBV) 


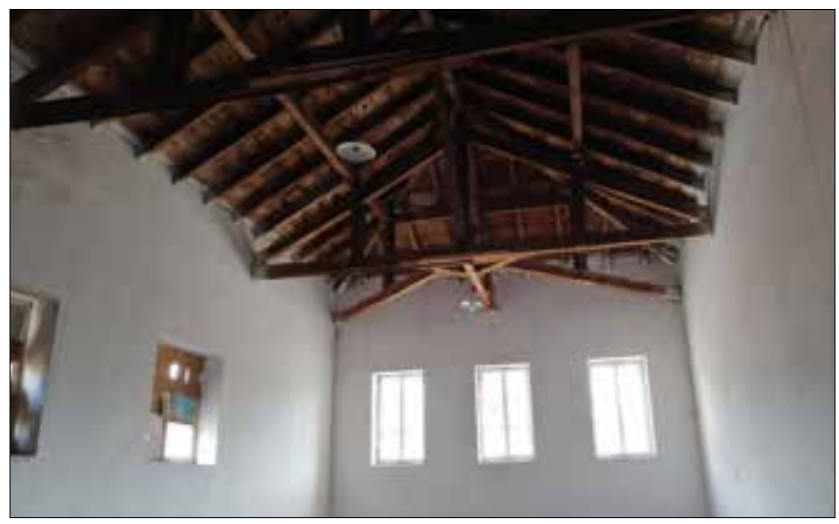

Figure 27: Gable roof of a storage building from the inside (Eken 2020). / Depo binasının iç mekânından beşik çatının görünümü (Eken 2020)

truss system because its span was wider. According to the peasants, constructing a roof without a post was impossible. Having the same opinion as the peasants, Mualla Eyüboğlu instructed that the truss system should be constructed despite the original plan for a gable roof (Gurallar 2017, 95). Then, students and trainers began to construct each element of the truss system in a workshop building. Özkuçur $(2016,147)$ explains the construction process of truss system as flows:

"...The dining hall, the roof of which will be built, had 45 meters length and 20 meters wide. Two of our friends, together with Sili Layos, drew a measured and detailed plan of one of the trusses on the floor of one of the workshop buildings. The students cut the timber according to this plan and made the necessary connections with dovetail (locally called kurtağzl), sheet iron (locally called lama demiri) and bolts (locally called clvata). They brought the completed trusses to the front of the dining hall by sliding them over the snow with sleds, they piled them up..."

After transporting the trusses, they were placed on the walls, pulled with ropes, and connected to each other with ridge purlins (Figure 28; Güneri 2019, 59). The dining hall was only observed externally during the site survey, but details of the truss system were examined through archive documents (Figure 28).

Other buildings with a different type of roof were the music complex and country house, designed by Mualla Eyüboğlu. The music complex included a rectangular hall and semi-circular mass consisting of personal studying rooms attached to the hall at a point ${ }^{3}$. While the gable roof of the rectangular hall was covered with tiles,

\footnotetext{
Since this building resembled the shape of a sickle (orak) from a top view, it caused many ideological rumors within the village. Thus, a new rectangular building was added to the complex to change the total form (Erbil 2014, 98).
}

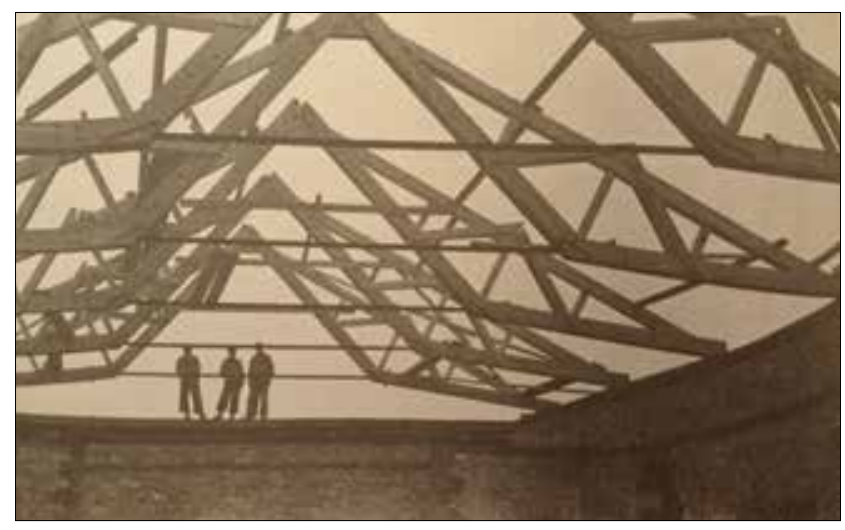

Figure 28: Truss roof of the dining hall (Güneri 2019, 82). / Yemekhane binasındaki çatı makası (Güneri 2019, 82)

the flat roof of the semi-circular mass was covered with lead plates to provide indoor acoustics and prevent the outflow of the sound ${ }^{4}$. Even though the music complex was restored in 2012, the authentic roof covering can be still observed on-site (Figure 29). The country house was constructed as an example of a traditional Hasanoğlan house, with an earthen flat roof. Eyüboğlu emphasized that the main purpose of constructing this type of building within the institute site was teaching solutions to students when they encountered problems in the village houses (Table 2, no: 63; Çokuğraş and Gençer 2018, 56).

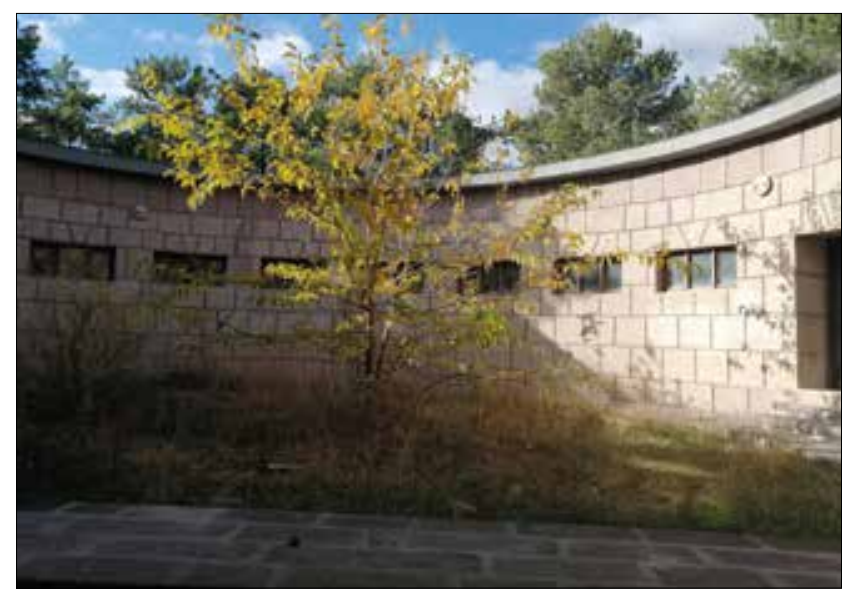

Figure 29: Flat-roofed semi-circular mass in the music complex (Eken 2020). / Müzik kompleksinde yer alan düz çatıl yarı dairesel kütle (Eken 2020)

After completing rough construction of the buildings, the final stage was assembly of the architectural elements shaped in the timber workshop according to the exact dimensions of the openings, and finishing the walls with plaster and whitewash (Figures 30 and 31) (Güneri 2019, $60)$. In terms producing the plaster, soaked sand was

\footnotetext{
4 This knowledge was gained by interviews with Ali Kinaci during the site survey.
} 


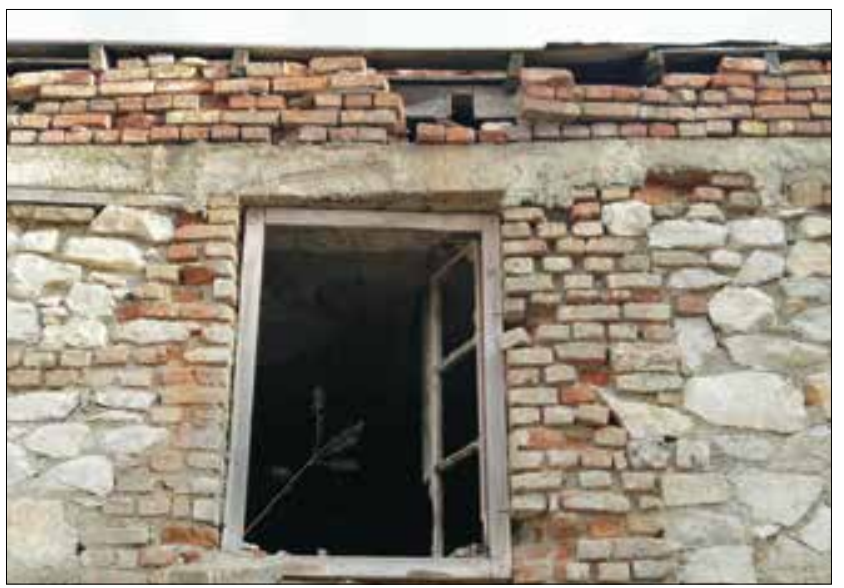

Figure 30: Unity of the brick-stone masonry wall, reinforced concrete slab, and wooden window in the bath complex (Eken 2020). / Hamam yapısındaki yı̆̆ma taş-tuğla duvar, betonarme döşeme ve ahşap pencere birlikteliği (Eken 2020)

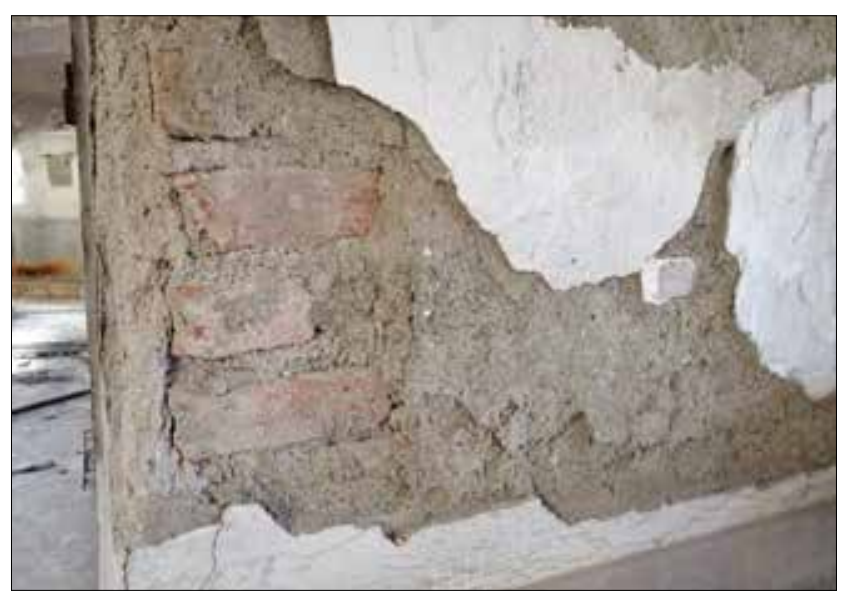

Figure 31: Details about finishing of the partition wall in the bath complex (Eken 2020). / Hamam yapısındaki ara duvarın bitiriş detayı (Eken 2020)

baked within stove-like braziers (locally called maltzz), which were also produced by students, and fine plaster was produced by adding sieved sand. Because it was the last item of the construction season, cold weather was the main challenge for students. Thus, Özkuçur $(2016,148)$ stated that straw bags were stacked in one corner of the space to create smoke burning them to prevent the plaster from freezing.

In addition to the buildings, organizing the open spaces for social activities was also significant during construction. Among them, the open-air theater was a unique structure. It included a scenery wall, two open backstage rooms on both sides of the wall, and a large circular sitting area in front of the wall was designed by Mualla Eyüboğlu and constructed by the students. According to Ali Kinac1, Ankara stones were used to construct the structure. While constructing the sitting area, the earthen land was first transformed into steps and stones were then put on these steps (Figures 32 and 33).
While the memories lacked details regarding the construction of the open-air theater, each former student had memories of this structure, as the foundation anniversary celebrations were held in it, during which time the students staged many Moliere, Sofokles, and William Shakespeare theater plays (Güneri 2019, 124). Many politicians, foreign guests, and artists were also hosted there. Although it is not used by students currently, some events are there by foundations interested in village institutes to increase awareness of the cause.

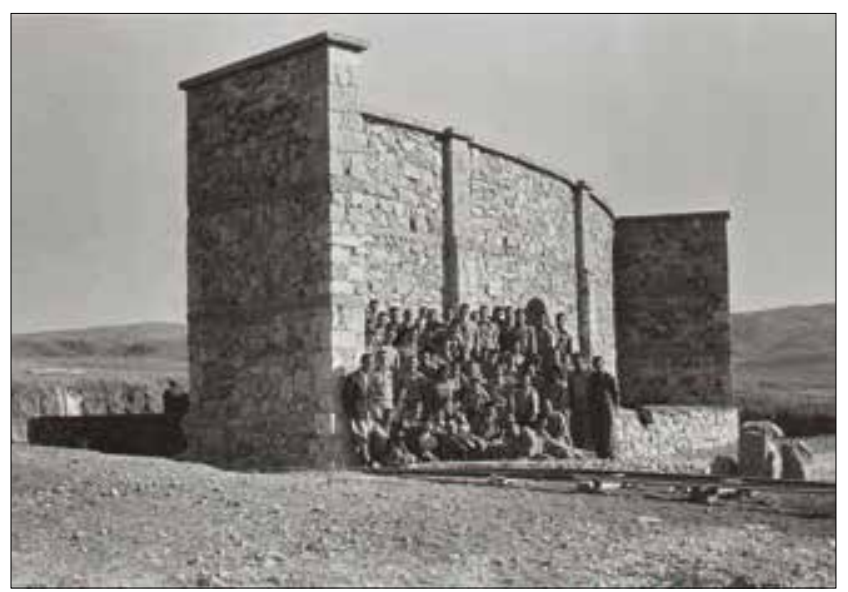

Figure 32: Students after constructing the scenery wall in the open-air theater (IHTBV). / Açık hava tiyatrosunun sahne duvarını inşa ettikten sonra öğrenciler (IHTBV)

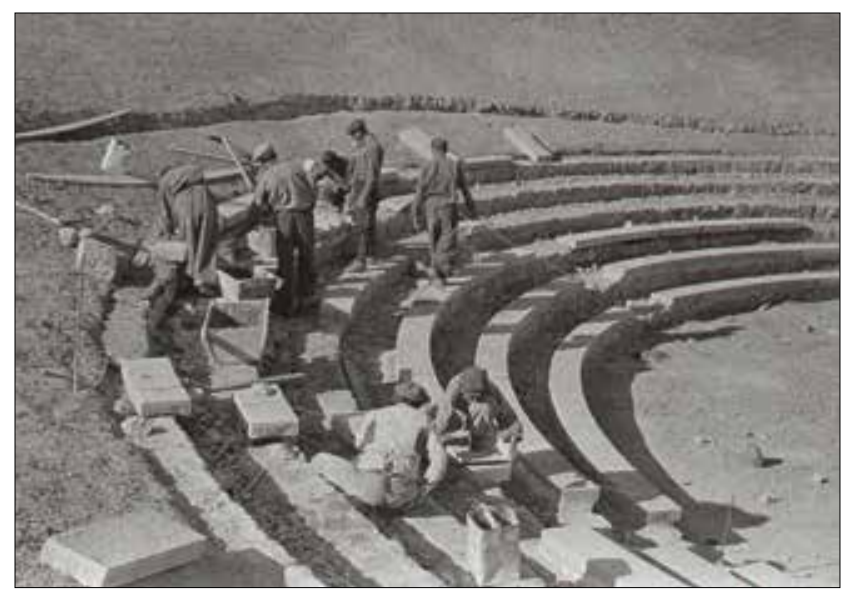

Figure 33: Construction of the sitting area of the open-air theater (IHTBV). / Açık hava tiyatrosunun oturma alanının inşası (IHTBV)

\section{STORY OF HASANOĞLAN VILLAGE INSTITUTE AFTER 1954}

Education continued to be given at the HVI until the 1950s, with the main ideology of village institutes as "iş içinde, iş aracılığıyla, iş için (in the work, through work, for work)". However, starting with the political change in Turkey at the end of the 1940s, adverse reactions occurred on the grounds that anti-government opinions had been 
imposed from village institutes. Based on the law entered into force in 1954, the HVI was transformed to a Primary Teacher School (Atatürk İlkögrretmen Okulu), like other village institutes (Çorakbaş 2013, 326). Following, educational function of the site has continued over the years with different names.

The site at present hosts the Hasanoğlan Atatürk Science High School (Hasanoğlan Atatürk Fen Lisesi). However, 26 buildings have been abandoned among the 40 existing original institute buildings. Additionally, 30 original institute buildings are lost at present, and it can be thought that 14 of which were destroyed intentionally to construct new buildings according to comparison of aerial photos in different time periods. New educational and residential buildings have been constructed in place of collapsed/intentionally destroyed buildings or structureless spaces (shown in Figure 2b; Tables 2 and 3; Çakıcı and Çorakbaş 2009).

Among the institute buildings that still exist, while two schools, three dormitories, ten teacher residences, an administrative building, timber, iron, painting, and tailor workshops, bakery, bath complex, music complex including cinema hall addition, dining hall, and activity center are abandoned; a workshop, three guest residences, a printing house, infirmary, country house, and higher-institute building continue to be used through refunctioning of them (Tables 2 and 3). Additionally, a new vocational school was constructed in place of an original institute school (Figure 2b, no: 1). On the other hand, five schools, six workshops, and two dormitories are lost, and new educational buildings, including the main schools, sport center, conference building, and multi-story teacher residences were constructed in place the collapsed institute buildings. In addition, new dormitories, personal residences and education centers have been constructed in the structureless spaces (shown in Figure 2b; Table 3).

Buildings at the site are presently surrounded by forests and depending on changes in the built environment, new axes have been created between the trees and buildings (Figure $2 b)$. However, the original agricultural land at the north appears as steppe. Additionally, some small sculptures created by institute students are exhibited in front of the administrative building and in the open space behind the ceremonial square, although large sculptures like "Tohum Saçan Köylü (seed-throwing peasant)" and the copy of Semendirek Nike have been destroyed ${ }^{5}$ (Figure 34).

\footnotetext{
5 According to the narratives of Özkuçur "Tohum Saçan Köylü" was shaped by Abdullah Özkuçur, a former student of the ÇVI, and located close to the site entrance. The Semendirek Nike sculpture, which was located in front of the open-air theater according to the narrative of Ali Kınacı (graduate of Atatürk Primary Teachers
}

Depending on the architectural, commemorative, historic, documentary, regional, executive, and political values of HVI as a whole (Çakıcı and Çorakbaş 2013) and the tendency to demolish existing buildings to construct new buildings, the first legal actions to conserve the institute site began in 2003 .

First, the open-air theater, music complex, and higherinstitute building were registered as cultural property by the Ankara Kültür Varlıklarını Koruma Bölge Kurulu (KTVKBK; Regional Board for the Preservation of Cultural Heritage). Among these buildings, the higherinstitute building was refunctioned as a museum and library. Additionally, the KTVKBK decided to preserve the murals on the walls of the conference hall in the music complex in 2005 (Figure 35). Although the registration decision was given for three buildings, the fact that these buildings were located on a single large parcel comprising the majority of the original institute buildings and open spaces, new construction activities in site are subject to permission of KTVKBK.

However, decision No. 1965, given on 8 December 2006 by the Ankara KTVKBK indicated that the institute buildings, excluding registered buildings, could be demolished and new structures compatible with the institute buildings could be built. Therefore, high-rise residential buildings and school complexes incompatible with the original institute buildings continue to be used rather than the repair and use of existing institute buildings.

In June 2007, a national student competition entitled "Evaluation Project of Hasanoğlan Village Institute and High Village Institute Campus (Hasanoğlan Köy Enstitüsü ve YüksekKöy Enstitüsü Yerleşkesi Değerlendirme Projesi)" was organized by the Ankara Branch of the Chamber of Architects. In addition to this competition, workshops and conferences organized by different foundations until 2012 have increased awareness regarding conservation of the HVI. As a result, in 2012, restoration work began for the music complex, open-air theater, and higher-institute building in cooperation with the Elmadag Municipality and Ministry of Culture and Tourism. Restoration of these three structures were completed within 2 years.

As of 2021, a project prepared by the Ankara Metropolitan Municipality Department of Cultural and Natural Heritage Preservation that will focus on the restoration of the bath complex, timber and iron workshops, and museum building, in addition to a landscape plan, reached the evaluation stage. However, there is still no integrated or holistic conservation policy for the HVI.

School, Atatürk Illkögretmen Okulu, established after the HVI closed in 1954) has also been lost; it can be seen in the old photograph, with a view towards the dining hall and activity center. 


\begin{tabular}{|c|c|c|c|c|c|}
\hline \multicolumn{6}{|c|}{ ORIGINAL INSTITUTE BUILDINGS CONSTRUCTED BEFORE 1948 \& PUBLIC OPEN SPACES } \\
\hline Building & Function & Current Function & Building & Function & Current Function \\
\hline 1 & School & Abandoned & 39 & Medical Building & Vocational School \\
\hline 2 & School & Abandoned & 40 & Stable & Collapsed \\
\hline 3 & School & Abandoned & 41 & Stable & Collapsed \\
\hline 4 & School & Collapsed & 42 & Stable & Collapsed \\
\hline 5 & School & Abandoned & 43 & Stable & Collapsed \\
\hline 6 & School & Collapsed & 44 & Coop & Collapsed \\
\hline 7 & School & Collapsed & 45 & Coop & Collapsed \\
\hline 8 & School & Collapsed & 46 & Dormitory & Collapsed \\
\hline 9 & Workshop & Masjid & 47 & Dormitory & Collapsed \\
\hline 10 & Workshop & Collapsed & 48 & Dormitory & Abandoned \\
\hline 11 & Workshop & Collapsed & 49 & Dormitory & Abandoned \\
\hline 12 & Workshop & Collapsed & 50 & Dormitory & Abandoned \\
\hline 13 & Workshop & Collapsed & 51 & Dormitory & Collapsed \\
\hline 14 & Workshop & Collapsed & 52 & Teacher's Residence & Abandoned \\
\hline 15 & Painting Workshop & Abandoned & 53 & Teacher's Residenee & Abandoned \\
\hline 16 & Iron Workshop & Abandoned & 54 & Teacher's Residence & Abandoned \\
\hline 17 & Timber Workshop & Abandoned & 55 & Teacher's Residence & Abandoned \\
\hline 18 & Tailor Workshop Electric Plant & Abandoned & 56 & Teacher's Residence & Abandoned \\
\hline 19 & Practicing Workshop & Gendamerie Headquarter & 57 & Teacher's Residence & Abandoned \\
\hline 20 & Storage for Workshop & Collapsed & 58 & Teacher's Residence & Abandoned \\
\hline 21 & Storage for Workshop & Collapsed & 59 & Teacher's Residence & Abandoned \\
\hline 22 & Storage for Workshop & Collapsed & 60 & Teacher's Residence & Abandoned \\
\hline 23 & Storage for Workshop & Collapsed & 61 & Teacher's Residence & Abandoned \\
\hline 24 & Storage for Workshop & Collapsed & 62 & Teacher's Residenee & Collapsed \\
\hline 25 & Storage for Workshop & Collapsed & 63 & Country House & Abandoned \\
\hline 26 & Storage for Food & Abandoned & 64 & Storage for Products & Collapsed \\
\hline 27 & Storage for Workshop & Collapsed & 65 & Guest Building & Teacher's Residence \\
\hline 28 & Storage for Workshop & Collapsed & 66 & Guest Building & Teacher's Residence \\
\hline 29 & Dining Hall \& Activity Center & Abandoned & 67 & Guest Building & Teacher's Residence \\
\hline 30 & Printing House & Medical Building & 68 & Toilet & Collapsed \\
\hline 31 & Administrative Building & Abandoned & 69 & Toilet & Collapsed \\
\hline 32 & Higher Institute Building & Museum-Library & 70 & Toilet & Collapsed \\
\hline 33 & Bath Complex \& Laundry & Abandoned & 71 & Ceremony Square & Ceremony Square \\
\hline 34 & Garrage & Abandoned & 72 & Football Field & Football Field \\
\hline 35 & Garrage & Abandoned & 73 & Volleyball Field & Volleyball Field \\
\hline 36 & Bakery & Abandoned & 74 & Agricultural Land & Steppe Area \\
\hline 37 & Open-Air Theatre & Open-Air Theatre & 75 & Steppe Area & Forrested Area \\
\hline 38 & Music Complex & Abandoned & 76 & Station Building & Collapsed \\
\hline
\end{tabular}

Table 2: Situation of the original institute buildings on-site / Alandaki özgün enstitü binalarının mevcut durumu

\section{CONCLUSION}

Even though 21 village institutes were distributed homogeneously to the whole country and completed their establishment within eight years (1940-1948), the village institute project is the product of a long process that started with the declaration of the Republic. Since this process aims to develop by using the dynamics within the country, agriculture and education have been handled together.

Since each region of Turkey has different geographical, social and economic characteristics, the construction story of each institute has its own unique differences.
Hasanoğlan village institute (HVI) has a special significance in terms of being central position among all institutes, having a higher institute department within its structure, and having a construction process that was based on direction of experts and student workforce. To understand physical characteristics and changes in the site over time, recent architectural studies regarding HVI were analyzed, site surveys were conducted, and old aerial photos were overlapped. However, these surveys based on analyzing tangible characteristics of the site are not adequate to depict its story including memories of people. At this point, memories of people who have been at HVI for part of their life are significant sources to understand establishment process and construction story of institute. 


\begin{tabular}{|c|c|c|c|c|c|}
\hline \multicolumn{6}{|c|}{ BUILDINGS CONSTRUCTED BETWEEN 1948 AND 2020} \\
\hline \multicolumn{6}{|c|}{ LEGEND } \\
\hline & \multicolumn{2}{|l|}{ Buildings constructed after 1948} & \multirow[b]{3}{*}{ Building } & \multicolumn{2}{|c|}{ Buildings construeted after 1991} \\
\hline & \multicolumn{2}{|l|}{ Buildings constructed after 1956} & & \multicolumn{2}{|c|}{ Buildings constructed after 1999} \\
\hline Building & Function & Current Function & & \begin{tabular}{|l|l|} 
Function \\
\end{tabular} & Current Function \\
\hline 77 & Sport Center & Sport Center & 83 & Teacher's Residences & Teacher's Residences \\
\hline 78 & Teacher's Residence Complex & \begin{tabular}{|l|}
$\begin{array}{l}\text { Teacher's Residence } \\
\text { Complex }\end{array}$ \\
\end{tabular} & 84 & Cinema Hall & Abandoned \\
\hline 79 & New School Building Complex & $\begin{array}{l}\text { New School Building } \\
\text { Complex }\end{array}$ & 85 & $\begin{array}{l}\text { Central Heating System } \\
\text { Building }\end{array}$ & Abandoned \\
\hline 80 & Dormitories & Dormitories & 86 & Conference Building & Conference Building \\
\hline 81 & $\begin{array}{l}\text { Atatork Science Highschool } \\
\text { Complex }\end{array}$ & $\begin{array}{l}\text { Atatark Science Highschool } \\
\text { Complex }\end{array}$ & 87 & $\begin{array}{l}\text { People's Education } \\
\text { Center }\end{array}$ & Abandoned \\
\hline 82 & Personel\&Teacher's Residences & Unobserved & u & $\begin{array}{l}\text { Buildings that have } \\
\text { unknown function }\end{array}$ & Abandoned \\
\hline
\end{tabular}

Table 3: Situation of the buildings constructed between 1948 and 2020. / 1948 ve 2020 yılları arasında inşa edilmiş binaların mevcut durumu

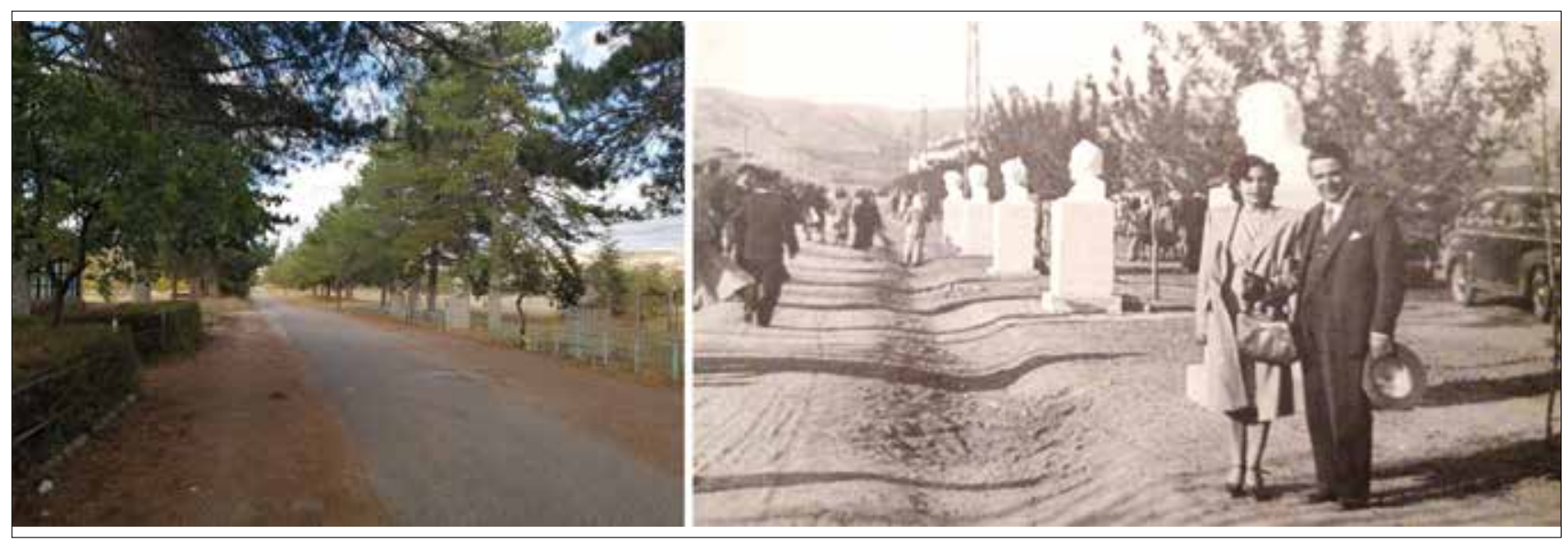

Figure 34: Main axis with the sculptures presently (left; Eken 2020) and in 1946 (right; Güneri 2019, 188). / Heykellerle çevrili ana aksın mevcut durumu (solda; Eken 2020) ve 1946 yllındaki durumu (sağda; Güneri 2019, 188)
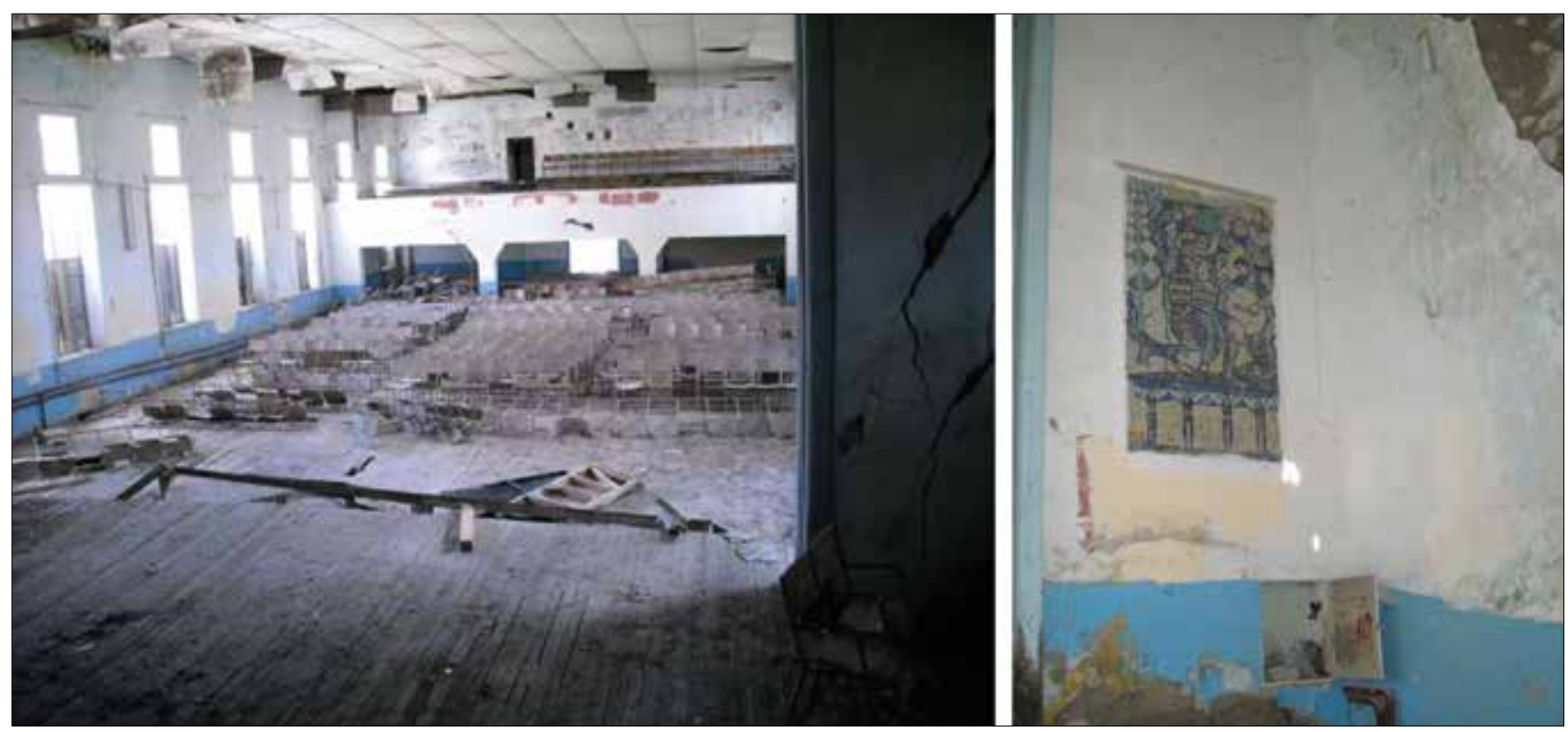

Figure 35: Inside the conference hall in the music complex (left) and a moral painting on the wall (right; Köy Enstitüleri ve Çağdaş Eğitim Vakfı (KEÇEV) (Village Institutes and Contemporary Education Foundation) 2011). / Müzik kompleksinde yer alan konferans salonun iç mekânı (solda; KEÇEV) ve duvar resimleri (sağda; KEÇEV) 
The study shows that construction process ofHasanoğlan Village Institute (HVI) is well planned beginning from the site selection to the construction of last building in the site. Even the institute buildings were totally constructed by student's workforce depending on the main ideology of institute based on learning by doing, the whole process has progressed with the guidance of experts in the field. The architectural project of the institute was prepared by the leading architects of the period depending on the site characteristics and main requirements of the educational program.

Although the construction works was completed faithfully to the determined project, especially the masters employed from Hungary and the architects assigned to the field, such as Mualla Eyüboğlu, produced instant solutions to the problems that emerged in the application and guided the students. During application of the projects, traditional construction materials like stone, brick and adobe were integrated with modern construction materials like concrete, nail and iron. Depending on the special function of some spaces, modern construction technique and materials were used in these buildings, such as construction of the roof of large dining space with truss system, covering the roof of music complex with led for acoustic. Architects and experts have aimed endurance of the buildings combining the traditional and modern technique. In this way, more suitable interior spaces and built environment would be created.

As a reflection of modern life standarts, Hasanoğlan and surrounding villages also got electricity through the institute. Villagers in Hasanoğlan attained a healthier living environment with the work of the institute students, such as building a şadırvan above the spring water in the village. Also, new water resources were moved to the settlement through the underground system with the efforts of the students.

In addition to all the buildings emphasized as essential in the specification of architectural competition, buildings with functions reflecting modern life such as open-air theater, music hall and cinema hall were designed by Mualla Eyüboğlu and implemented to the site creating a social zone at north. Additionally, Mualla Eyüboğlu also designed a country house that was constructed with totally traditional construction technique and material to prepare students for the problems they may encounter in the houses of villages where they are teachers. Thus, modern and traditional life standards were also combined through education.

Depending on these special planning and construction process of Hasanoğlan Village Institute, studies towards understanding its significance and conserving it should be increased with a holistic approach. This study, which handles the unique construction story of HVI in a historical context, is significant to raise awareness about HVI with other institutes.

\section{ACKNOWLEDGEMENT}

The authors wish to thank İsmail Hakkı Tonguç Belgeliği Vakfı, Köy Enstitüleri ve Çağdaş Eğitim Vakfi, and Ankara Büyükşehir Belediyesi Kültür ve Tabiat Varlıkları Daire Başkanlığı for their cooperation during the study. 


\section{REFERENCES}

ALADAĞ, A. 2019.

"Conservation of Village Institutes as A Heritage of Early Republican Period: Ivriz Village Institute", Master Thesis. Graduate Program in Conservation of Cultural Heritage. Middle East Technical University.

ALTUNYA, N., KINACI, A. 2019.

"Hasanoğlan Yüksek Köy Enstitüsü", Ankara:

Telgrafhane Yayınları.

APAYDIN, T. 2020.

“Köy Enstitüsü Yılları. İstanbul: Literatür Yayınları.

ARMAN, H. 2016.

"Piramidin Tabanı Köy Enstitüleri ve Tonguç", İzmir: Yeni Kuşak Köy Enstitüler Derneği Yayınları.

ATICI, E. 2010.

"Anadolu'da Aydınlanma Ateşini Yakanlar", Ankara:

Köy Enstitüleri ve Çağdaş Eğitim Vakfı Yayınları.

AYSAL, N. 2005.

“Anadolu'da Aydinlanma Hareketi'nin Doğuşu: Köy Enstitüleri”, Ankara Üniversitesi Türk Inkılap Tarihi Enstitüsü Atatürk Yolu Dergisi (35-36), 267-282.

BAŞGÖZ, İ. 1995.

"Türkiye'nin Eğitim Çıkmazı ve Atatürk". Ankara: Kültür Bakanlığı Yayını.

BAYKURT, F. 2016.

"Unutulmaz Köy Enstitüleri”. İstanbul: Literatür Yayınları.

CANDAN, Ü. 2008.

"Sanat Eğitimi, Sanat ve Köy Enstitüleri", Mersin Üniversitesi Eğitim Fakültesi Dergisi (4), 37-45.

ÇAKICI, S., AND ÇORAKBAŞ, F. K. 2013.

"Hasanoğlan Köy Enstitüsü Ve Yüksek Köy Enstitüsü Yerleşkesi'nin Tarihçesi Ve Değerleri”, Mimarlık, 369, 66-72.

ÇOBAN, F. 2010.

"KöyEnstitüsüMezunu ÖğretmenlerinKöyEnstitüsündeki Öğretmen Algıları Ve Sinıf Yönetimi Anlayışı", Master Thesis. Eğtim Bilimleri. Muğla Üniversitesi.

ÇOKUĞRAŞ, I., AND GENÇER, C. İ. 2018.

"Çok Yönlü Bir Cumhuriyet Mimarı: Mualla Eyüboğlu Anhegger", Mimarlık, 403, 55-60.
ÇOLAK, M. 2004.

"Cumhuriyetin Kuruluş Yıllarında Türk Eğitim Yaşamında Macar Ĕgitimcilerin Yeri", Atatürk Araştırma Merkezi Dergisi, 231-243.

ÇORAKBAŞ, F. K. 2014.

"Mimari Koruma Perspektifinden Ortaklar Köy Enstitüsü Yerleşkesi ve Mualla Eyüboğlu", In: K Kocabaş (ed), Ortaklar Köy Enstitüsü 70 Yaşında, Yeni Kuşak Köy Enstitülüler Derneği Yayınları, 105-116.

ÇORAKBAŞ, F. K., AND ATALAY, B. 2017.

"Beşikdüzü Köy Enstitüsü Yerleşkesi: Mekansal Hafizanın Yıkımı", In: K. Kocabaş (ed.), Tanıklıklarla Beşikdüzü Aydınlığı, Yeni Kuşak Köy Enstitülüler Derneği Yayınları, 113-128.

ÇORAKBAŞ, F. K., AND DENIZ YEŞILTEPE, A. "Köy Enstitüleri Yerleşkelerinde Eğitim Sistemi Değişikliklerinin Mekansal Yansimalarl: Erzurum Pulur Köy Enstitüsü Yerleşkesi”, Sosyal Bilimler Enstitüsü, 10-11, 149-165.

ÇORAKBAŞ, F. K., AND SÜMERTAŞ, F. M. 2014.

"Çifteler Köy Enstitüsü Yerleşkelerinin Mekansal Süreklilik Ve Dönüşümleri”, Mimarlık, 380.

ÇORAKBAŞ, F. K. 2013.

"Hasanoğlan Köy Enstitüsü ve Yüksek Köy Enstitüsü Yerleşkesinin Mekansal Tarihi, Mimari Değerleri ve Korunması", In: K. Kocabaş (ed.), Hasanoğlan Yüksek Köy Enstitüsü 70 Yaşında, Yeni Kuşak Köy Enstitülüler Derneği Yayınları, 322-336.

DÖNMEZ, R. 1945.

"Hasanoğlan Köy Enstitüsü’nün Kısa Tarihçesi." Köy Enstitüleri Dergisi (1), Ankara: Maarif Matbaası.

ERBIIL, M. 2014.

"Köy Enstitüleri ve Yurtseverlik", Ankara: Payda Yayıncılık.

GAZALCI, M. 2018.

"Köy Enstitüleri Sistemi”, Ankara: Bilgi Yayınevi.

GURALLAR, N. 2017.

"Mimar Mualla Eyüboğlu Anhegger: Meslek ve Yaşam Öyküsü Üzerine Notlar", Toplumsal Tarih (279), 90-96.

GÜNERİ, M. 2019.

"Hasanoğlan Hatırası", İstanbul: Türkiye İş Bankası Yayınları.

HIZLI ERKILIÇ, N. 2011.

"ÇevreSistemine Dayalı Kırsal Mimari Tasarımı: Eskişehir Çifteler Köy Enstitüsü”, Çevre Tasarım Kongresi, 8-9 Arallk 2011, Yıldız Teknik Üniversitesi, İstanbul. 
JOHN, D. 1939.

"Türkiye Maarifi Hakkında Rapor". İstanbul: Maarif Vekilliği Devlet Basımevi.

KARTAL, S. 2008.

"Toplum Kalkınmasında Farklı Bir Eğitim Kurumu: Köy Enstitüleri”, Mersin Üniversitesi Eğitim Fakültesi Dergisi (4), 23-36.

KARADENIZ, E. 2019.

"Erken Cumhuriyet Dönemi Modernlik Arayışının Yansımaları: Beşikdüzü Köy Enstitüsü’, Master Thesis. Architecture. Karadeniz Technical University.

KIRBY, F. 1962.

“Türkiye’de Köy Enstitüleri”, İmece Yayınları.

KÖY ENSTITÜLERI VE ÇAĞDAȘ EĞITIM VAKFI. 2003.

“Köy Enstitüleri 1-2”, Ankara: Köy Enstitüleri ve Çağdaş Eğitim Vakfi Yayınları.

KÜHNE. 1939.

"Mesleki Terbiyenin Inkişafina Dair Rapor". İstanbul: Maarif Vekilliği Devlet Basımevi.

MENEKŞE, N. 2005.

“Kapatılışlarının 58. ve Kuruluşlarının 72. Yılında Köy Enstitüleri Gerçeğì, İzmir.

MERCANOĞLU, C. 2019.

"Relationship Between Sense of Belonging and Social Production of Space: Analysis of Hasanoğlan High Village Institute", Master Thesis. City Planning in City and Regional Planning. Middle East Technical University.

OMAR, B. 1939.

"Teknik Öğretim Hakkında Rapor". İstanbul: Maarif Vekaleti.

ÖZDEMIR, A. 2017.

"Malatya Akçadağ Köy Enstitüsü ve kullanım durumu", Master Thesis. Architecture. Dicle University.

ÖZKUÇUR, A. 2013.

“Hasanoğlan Yüksek Köy Enstitüsü”, Ankara: Köy Enstitüleri ve Çağdaş Eğitim Vakfı Yayınları.

ÖZKUÇUR, A. 2016.

"Köy Enstitüleri Destanı", Ankara: Köy Enstitüleri ve Çağdaş Eğitim Vakfı Yayınları.

RATING ACADEMY. 2019.

“Köy Enstitüleri Felsefesini Geleceğe Taşımak”, M Şahin and M A Başar (eds). Çanakkale: Rating Academy Yayınları.
ŞEREN, M. 2008.

"Köye Öğretmen Yetiştirme Yönüyle Köy Enstitüleri", Gazi Eğitim Fakültesi Dergisi (28), 203-226.

TEKBEN, Ş. 1962.

“Neden Köy Enstitüleri?”. İstanbul: Türkiye Milli Gençlik Teşkilatı Gençlik Yayınları.

TONGUÇ, E. 1970.

“Devrim Açısından Köy Enstitüleri ve Tonguç”, İstanbul: Ant Yayınları.

TONGUÇ, İ. H. 1997.

“Kitaplaşmamış Yazılar (Cilt 1)", Ankara: Köy Enstitüleri ve Çağdaş Eğitim Vakfı Yayınları.

UYGUN, S. 2007.

"Tanıkların Dilinden Bir Dönem Öğretmen Okullarl: Ilköğretmen Okullarl ve Köy Enstitüleri”, Ankara: Milli

Eğitim Bakanlığı.

VAROL, T. A. 2020.

“Köy Enstitüsü Sisteminin Tarihsel Temelleri”, Master Thesis. Eğitim Bilimleri. Bursa Uludağ Üniversitesi.

YASA, İ. 1969.

"Yirmibeş Yll Sonra Hasanoğlan Köyü”, Ankara: Ankara

Üniversitesi Siyasal Bilgiler Fakültesi Yayınları.

YILDIRIM, S. 2012.

"Cumhuriyet Döneminde Türk Macar Ilişkileri Çerçevesinde Istihdam Edilen Macar Uzmanlar", Cumhuriyet Tarihi Araştırmaları Dergisi, 8, 15, 121150. 